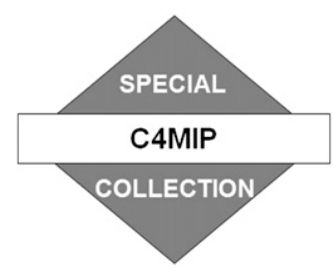

\title{
Effect of Anthropogenic Land-Use and Land-Cover Changes on Climate and Land Carbon Storage in CMIP5 Projections for the Twenty-First Century
}

\author{
V. Brovkin, ${ }^{*}$ L. Boysen, ${ }^{*}$ V. K. Arora,${ }^{+}$J. P. Boisier, ${ }^{\#}$ P. CAdule, ${ }^{\#}$ L. Chini, ${ }^{@}$ M. Claussen, ${ }^{\&}$

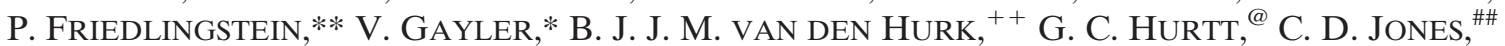 \\ E. KATO, ${ }^{@}$ N. DE NOBlet-DuCOUdRÉ, ${ }^{*}$ F. PACIFICO,** J. PONGRATZ,* AND M. WeisS ${ }^{++}$ \\ * Max Planck Institute for Meteorology, Hamburg, Germany \\ ${ }^{+}$Canadian Centre for Climate Modelling and Analysis, Environment Canada, \\ University of Victoria, Victoria, British Columbia, Canada \\ \# Laboratoire des Sciences du Climat et de l'Environnement, Gif-sur-Yvette, France \\ ${ }^{@}$ University of Maryland, College Park, College Park, Maryland \\ \& Max Planck Institute for Meteorology, and University of Hamburg, Hamburg, Germany \\ ** University of Exeter, Exeter, United Kingdom \\ ${ }^{++}$Netherlands Royal Meteorological Institute, De Bilt, Netherlands \\ \#\# Met Office Hadley Centre, Exeter, United Kingdom \\ ${ }^{@}$ National Institute for Environmental Studies, Tsukuba, Japan
}

(Manuscript received 27 July 2012, in final form 26 February 2013)

\begin{abstract}
The effects of land-use changes on climate are assessed using specified-concentration simulations complementary to the representative concentration pathway 2.6 (RCP2.6) and RCP8.5 scenarios performed for phase 5 of the Coupled Model Intercomparison Project (CMIP5). This analysis focuses on differences in climate and land-atmosphere fluxes between the ensemble averages of simulations with and without land-use changes by the end of the twenty-first century. Even though common land-use scenarios are used, the areas of crops and pastures are specific for each Earth system model (ESM). This is due to different interpretations of land-use classes. The analysis reveals that fossil fuel forcing dominates land-use forcing. In addition, the effects of land-use changes are globally not significant, whereas they are significant for regions with land-use changes exceeding $10 \%$. For these regions, three out of six participating models-the Second Generation Canadian Earth System Model (CanESM2); Hadley Centre Global Environmental Model, version 2 (Earth System) (HadGEM2-ES); and Model for Interdisciplinary Research on Climate, Earth System Model (MIROC-ESM) - reveal statistically significant changes in mean annual surface air temperature. In addition, changes in land surface albedo, available energy, and latent heat fluxes are small but significant for most ESMs in regions affected by land-use changes. These climatic effects are relatively small, as land-use changes in the RCP2.6 and RCP8.5 scenarios are small in magnitude and mainly limited to tropical and subtropical regions. The relative importance of the climatic effects of land-use changes is higher for the RCP2.6 scenario, which considers an expansion of biofuel croplands as a climate mitigation option. The underlying similarity among all models is the loss in global land carbon storage due to land-use changes.
\end{abstract}

\section{Introduction}

About one-third to one-half of the land surface has been modified by humans (Ellis 2011; Vitousek et al. 1997), and the land-use extent is likely to increase in the future to accommodate a growing demand for land

Corresponding author address: V. Brovkin, Max Planck Institute for Meteorology, Bundesstr. 53, 20146 Hamburg, Germany. E-mail: victor.brovkin@zmaw.de
(Carpenter et al. 2006). Anthropogenic land-use and land-cover change (LULCC) affects climate through two different pathways. The biogeophysical pathway considers alteration of the physical characteristics of the land surface such as albedo, soil moisture, and roughness. The second, the biogeochemical pathway, takes into account alterations of the atmospheric concentrations of greenhouse gases (GHGs) such as $\mathrm{CO}_{2}, \mathrm{CH}_{4}$, and $\mathrm{N}_{2} \mathrm{O}$ in response to changes in the land-atmosphere fluxes of these trace gases (Arora and Boer 2010; Canadell et al. 
2007; Houghton 2003; House et al. 2002; Pongratz et al. 2009; Shevliakova et al. 2009). Numerous biogeophysical and biogeochemical processes are parameterized in the land surface schemes of atmospheric general circulation models (AGCMs). These schemes simulate the exchange of heat, moisture, and $\mathrm{CO}_{2}$ between the land surface and the atmosphere (e.g., Bonan 2008; Dickinson et al. 1993; Sellers et al. 1997). LULCC was previously shown to result in seasonal changes in temperature, precipitation patterns, snow cover in high-latitude regions, and atmospheric dynamics (e.g., Bala et al. 2006; Chase et al. 2000; Claussen et al. 2004; Feddema et al. 2005).

The Land-Use and Climate, Identification of Robust Impacts (LUCID) project is focused on the biogeophysical effects of LULCC on climate. Pitman et al. (2009) investigated the climatic effect of land-cover changes from the preindustrial period to the present day using several AGCMs. The models simulated substantial changes in latent and sensible heat fluxes, albedo, and near-surface air temperature over the regions with considerable LULCC, although the magnitude of those LULCCinduced changes differed considerably among the models. De Noblet-Ducoudré et al. (2012) and Boisier et al. (2012) analyzed the mechanisms that explain those differences, and Pitman et al. (2012) showed that LULCC systematically affected temperature extremes. Van der Molen et al. (2011) showed that feedbacks in local cloud cover are important to explain differences between tropical and extratropical temperature responses to LULCC.

The LUCID experiments were designed to investigate the LULCC effects on climate using prescribed sea surface temperatures (SSTs) and sea ice, putting emphasis on land-atmosphere interactions. This approach allows isolation of the direct effects of LULCC on the atmosphere from the indirect effects caused by interactions with the other components of climate system (e.g., sea ice). However, neglecting these feedbacks may reduce the magnitude of effects of LULCC on climate (e.g., Davin and de Noblet-Ducoudré 2010). On decadal to centennial time scales, the feedbacks through interactive SSTs and sea ice have the potential to enhance the biogeophysical cooling that occurs in response to historical LULCC (Brovkin et al. 2006). Coupled atmosphereocean simulations are crucial for future climate change projections, because the ocean plays a dominant role in the climate response to high levels of GHG concentrations. Pitman et al. (2011) have demonstrated that LULCC impacts depend on the background climate. The climatic effect of LULCC in the future scenarios are generally secondary in comparison to the climatic effects of fossil fuel emissions (Sitch et al. 2005), while the magnitude and patterns of LULCC-induced climatic changes are scenario dependent.
Phase 5 of the Coupled Model Intercomparison Project (CMIP5) is a coordinated effort of more than 20 climate-modeling groups from around the world to improve our understanding of climate change (Taylor et al. 2012). Integrated Assessment Model (IAM) groups provided the CMIP5 community with four representative concentration pathways (RCPs) of greenhouse gases and aerosols and the associated land-use and land-cover changes through the twenty-first century. The set of RCP scenarios envelopes different scenarios of future land-use changes, which satisfy the demand for food, biofuels, and afforestation (or reforestation) to mitigate $\mathrm{CO}_{2}$-induced climate changes.

In the core set of CMIP5 simulations, Earth system models (ESMs) are driven through the twenty-first century by a set of RCP scenarios that include land-use changes. To isolate the effect of land-use changes on climate, several CMIP5 modeling groups performed additional LUCID-CMIP5 simulations without anthropogenic land-use changes from 2006 to 2100 . The differences between simulations with and without land-use changes reveal climatic effects of LULCC on global and regional scales. In this paper, we examine the biogeophysical effects and changes in the land carbon storage due to LULCC, focusing on two RCP simulations driven by prescribed $\mathrm{CO}_{2}$ concentrations. These simulations allow us to quantify the climatic effect of changes in land cover in comparison to those caused by changes in fossil fuel emissions for the RCP scenarios considered here. The intermodel comparison provides a quantitative assessment of the uncertainty in climatic effects of land-cover changes due to differences in model parameterizations.

\section{Experimental setup}

Two RCP scenarios were considered among the four scenarios of climate change over the twenty-first century. The RCP8.5 scenario produced by the Model for Energy Supply Strategy Alternatives and their General Environmental Impact (MESSAGE) IAM (Riahi et al. 2011) corresponds to a radiative forcing of more than $8.5 \mathrm{~W} \mathrm{~m}^{-2}$ and a $\mathrm{CO}_{2}$ concentration of $936 \mathrm{ppm}$ in 2100. It represents the upper 10th percentile of the future scenario range for $\mathrm{CO}_{2}$ emissions (Moss et al. 2010). In contrast, the RCP2.6 scenario simulated by the Integrated Model to Assess the Global Environment (IMAGE) IAM (van Vuuren et al. 2011) represents pathways in the lower 10th percentile of climate mitigation scenarios (Moss et al. 2010). The RCP2.6 scenario assumes a peak radiative forcing of $3.1 \mathrm{~W} \mathrm{~m}^{-2}$ around 2050 followed by a decline toward $2.6 \mathrm{~W} \mathrm{~m}^{-2}$ and a $\mathrm{CO}_{2}$ concentration of $420 \mathrm{ppm}$ in 2100. These two scenarios span the two extremes of projected climate change over the twenty-first century. 
Each of these scenarios is supplemented by a set of explicit LULCC data. Different reasons explain the substantial increase in cultivated land by the end of the twenty-first century in both scenarios. In the RCP8.5 scenario, the expansion of croplands and pastures is driven by the food demands of an increasing population, while in the RCP2.6 scenario the climate change mitigation is partly achieved by an increase in the area used for the production of bioenergy crops. The total global area used for pastures is more or less constant in RCP2.6 over the twenty-first century, as the increase in production of animal-based products is met through a shift from extensive to more intensive animal husbandry.

\section{a. Harmonized land-use change scenarios}

The IAM land-use scenarios are diverse; each operates with different classes of land cover and land use, different spatial and temporal resolutions, and different assumptions about the historical land-use reconstruction that the future projections are built on. In addition, the data from IAMs is not always in the format required by ESMs. These challenges are addressed using a "harmonized" set of RCP land-use change scenarios developed by Hurtt et al. (2011) that seamlessly connects gridded historical reconstructions of land-use with future projections in a format required by ESMs while preserving as much information from the future scenarios as possible. The Global Land-Use Model (Hurtt et al. 2006) was adapted and extended to produce new estimates of global land-use patterns (fractional content of crop, pasture, urban, primary land, and secondary land in each grid cell) and underlying annual land-use transitions (i.e., which type of land-use was converted to which different use and where) at $0.5^{\circ} \times 0.5^{\circ}$ resolution beginning in 1500 and connecting seamlessly in 2005 to the future projections provided by IAMs to 2100. Although the agreement between IAMs on 2005 land-use values was generally strong at the global scale, there were still significant regional differences. To address this issue, IAM decadal changes in land-use were aggregated over a $2^{\circ} \times 2^{\circ}$ grid, and these changes were applied sequentially to the 2005 land-use distribution of the History Database of the Global Environment, version 3.1 (HYDE3.1), database (Goldewijk et al. 2011). The resulting changes on $2^{\circ} \times 2^{\circ}$ grids were then disaggregated into changes on $0.5^{\circ} \times 0.5^{\circ}$ grids, weighted by available land for crop and pasture increases, and applied proportionally for cropland or pasture decreases. Finally, these decadal changes were interpolated temporally to get annual data. Resulting changes in landuse between 2005 and 2100 are shown in Fig. 1 for cropland (top), pasture (middle), and total agricultural land (bottom).
Two sets of LUCID-CMIP5 simulations, L2A26 and L2A85, were performed with the CMIP5 models using the same forcings as for the RCP2.6 and RCP8.5 experiments but with land-use prescribed to the state in 2006 (Table 1). Simulating an interactive ocean response is important to account for LULCC effects through SSTs and sea ice. This is inherent to the LUCID-CMIP5 simulations. The drawback of using an interactive ocean component is that it increases the variability of simulated climate and decreases the signal-to-noise ratio in sensitivity experiments using small forcings, such as LULCC. To explore the uncertainty related to internal climate variability, an ensemble of several members was performed if computationally affordable. The number of analyzed LUCID-CMIP5 simulations ranges from one for the Model for Interdisciplinary Research on Climate (MIROC); EC-Earth Consortium (EC-Earth); and L'Institut Pierre Simon Laplace Coupled Model, version 5, coupled with the Nucleus for European Modelling of the Ocean (NEMO) (IPSL-CM5A) models to three for the Second Generation Canadian Earth System Model (CanESM2) and Hadley Centre Global Environmental Model, version 2 (Earth System) (HadGEM2-ES) (Table 2).

\section{b. Implementation of land-use changes}

The harmonized scenarios of land-use change and woody harvest were implemented into the six participating ESMs in different ways following the structure of their land surface models. Brief descriptions of the physical model components, the land carbon cycle, and the implementation of LULCC into land surface schemes of the participating ESMs are provided in the appendix A.

Three out of the six models-EC-Earth, MIROCESM, and Max Planck Institute Earth System Model (MPI-ESM) - account for the transition matrix in the harmonization protocol by Hurtt et al. (2011). This transition matrix provides annual fractions of changes in the land grid cells from one land-use class to another. The implementation of this scheme has different consequences for the carbon cycle than for the vegetation cover. For example, a cyclic conversion of forest to pasture, pasture to cropland, and cropland to forest leads to no changes in land surface fractions covered by the particular plant functional types (PFTs) but however leads to a reallocation of the carbon reservoirs among the PFTs. This results in additional $\mathrm{CO}_{2}$ emissions that result from transitional changes in carbon pools due to simultaneous clearing and regrowth of forest although the net forest cover in the grid cell does not change.

Implementation of cropland into the land surface schemes of ESMs is very simplistic. Only CanESM2 explicitly models crop PFTs. Other ESMs treat cropland 

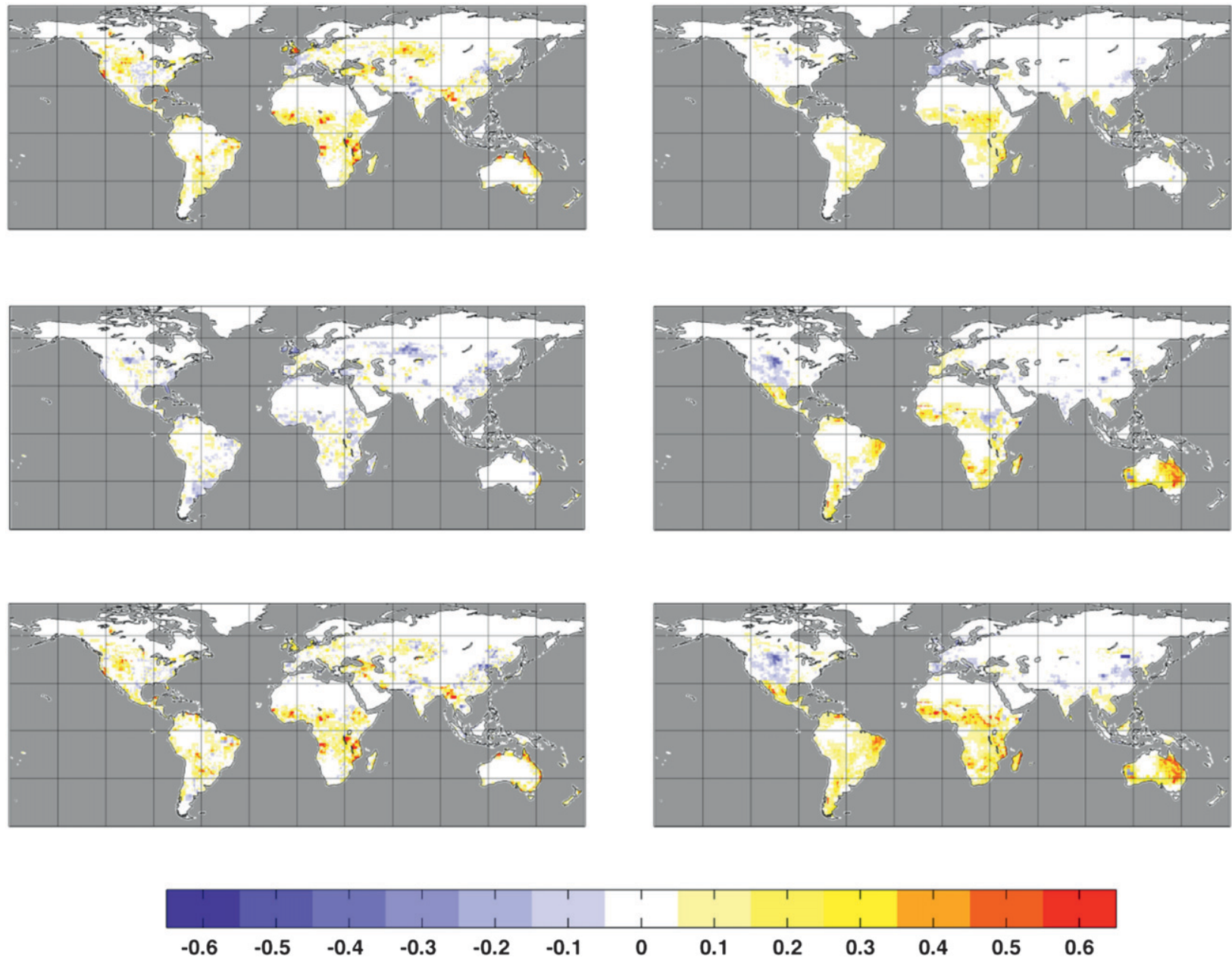

FIG. 1. Differences between years 2100 and 2005 in fractions of (top) pasture, (middle) cropland, and (bottom) cropland plus pasture in the RCP scenarios: (left) RCP2.6 and (right) RCP8.5.

as grassland with the same albedo and the same or slightly modified carbon cycle parameterization (MPIESM assumes different parameters of photosynthesis and phenology for crops). In all ESMs, a change from grassland to pasture does not lead to a significant change in land surface parameters.

ESMs account for changes in pastures in various ways. A spread among models is clearly visible in Fig. 2 for the RCP8.5 scenario, which assumes that a substantial part of western Australia is converted to pasture by
2100. Models with dynamic vegetation (HadGEM-ES, MIROC-ESM, and MPI-ESM) use this scenario in calculation of land-cover changes. CanESM2 does not account for changes in pastures assuming that this change in land use does not translate into changes in land cover. IPSL-CM5A and EC-Earth use observed vegetation cover, and this results in almost no changes in vegetation cover in Australia in RCP8.5. The diversity among the models in crop fractions is also considerable, although most of the patterns are reproduced in the

TABLE 1. List of model experiments.

\begin{tabular}{clcr}
\hline \hline Simulation acronym & Atmospheric GHGs, aerosols & Land use & Simulated years \\
\hline & & CMIP5 & \\
RCP2.6 & Transient scenario (RCP2.6) & Transient scenario (RCP2.6) & $2006-2100$ \\
RCP8.5 & Transient scenario (RCP8.5) & Transient scenario (RCP8.5) & $2006-2100$ \\
& & & $2006-2100$ \\
L2A26 & Transient scenario (RCP2.6) & Fixed to year 2006 & $2006-2100$ \\
L2A85 & Transient scenario (RCP8.5) & Fixed to year 2006 & \\
\hline
\end{tabular}


TABLE 2. Brief description of models participated in the LUCID-CMIP5 simulations. JULES is the Joint U.K. Land Environment Simulator based on the MOSES2 land surface scheme.

\begin{tabular}{|c|c|c|c|c|c|c|}
\hline ESM & CanESM2 & EC-Earth & HadGEM2-ES & IPSL-CM5A-LR & MIROC-ESM & MPI-ESM-LR \\
\hline $\begin{array}{l}\text { Atmosphere/land } \\
\text { resolution }\end{array}$ & $\sim 2.8^{\circ}$ & $\sim 1.1^{\circ}(\mathrm{T} 159)$ & $\sim 1.6^{\circ}$ & $3.75^{\circ} \times 1.90^{\circ}(\mathrm{T} 39)$ & $\sim 2.8^{\circ}(\mathrm{T} 42)$ & $\sim 1.9^{\circ}(\mathrm{T} 63)$ \\
\hline $\begin{array}{l}\text { Land surface } \\
\text { component }\end{array}$ & CTEM & HTESSEL & JULES & ORCHIDEE & SEIB-DGVM & JSBACH \\
\hline Number of PFTs & 9 & 15 & 5 & 13 & 13 & 12 \\
\hline Dynamic vegetation & No & No & Yes & No & Yes & Yes \\
\hline Fire module & No & No & No & Yes & No & Yes \\
\hline Crop PFT & Yes & Yes & No & Yes & $\mathrm{No}^{\mathrm{a}}$ & $\mathrm{No}^{\mathrm{b}}$ \\
\hline Pasture PFT & No & $\mathrm{No}^{\mathrm{c}}$ & Yes & $\mathrm{No}^{\mathrm{c}}$ & Yes & Yes \\
\hline Wood harvest & No & No & No & No & No & Yes \\
\hline $\begin{array}{l}\text { Usage of land-use } \\
\text { transitions } \\
\text { (Hurtt et al. 2011) }\end{array}$ & No & Yes & No & No & Yes & Yes \\
\hline $\begin{array}{l}\text { Ensemble members } \\
\text { (RCP2.6/L2A26) }\end{array}$ & $3 / 3$ & $1 / 1$ & $3 / 3$ & - & $1 / 1$ & $3 / 2$ \\
\hline $\begin{array}{l}\text { Ensemble members } \\
(\mathrm{RCP} 8.5 / \mathrm{L} 2 \mathrm{~A} 85)\end{array}$ & $3 / 3$ & $1 / 1$ & $3 / 3$ & $3 / 1$ & $1 / 1$ & $3 / 2$ \\
\hline ESM reference & $\begin{array}{l}\text { Arora et al. } \\
2011\end{array}$ & $\begin{array}{l}\text { Hazeleger et al. } \\
\text { 2012; } \\
\text { Weiss et al. } \\
2012\end{array}$ & $\begin{array}{l}\text { Collins et al. 2011; } \\
\text { Jones et al. 2011; } \\
\text { Martin et al. 2011 }\end{array}$ & $\begin{array}{l}\text { Dufresne et al. } \\
2013\end{array}$ & $\begin{array}{l}\text { Watanabe } \\
\text { et al. } 2011\end{array}$ & $\begin{array}{l}\text { Giorgetta et al. 2013; } \\
\text { Reick et al. } 2013\end{array}$ \\
\hline
\end{tabular}

${ }^{a}$ Uses grasses PFT parameters for crops but harvested annually.

${ }^{\mathrm{b}}$ Crops differ from grasses in parameters of photosynthesis and phenology.

${ }^{\mathrm{c}}$ Pastures are implicitly accounted.

tropics (Fig. 2). The temporal dynamics of crop area changes presented in Fig. 3 (top) show a relatively smaller spread between the models $[ \pm 1$ standard deviation $(\mathrm{SD})]$ in comparison with the pasture changes (Fig. 3, middle). On average, the RCP2.6 simulations show almost twice as high changes in crop areas as the RCP8.5 scenario. In contrast, the average decrease in tree cover in both simulations is very similar, although the spread in simulated tree fraction is more substantial than for the crop fraction (Fig. 3, bottom). Without land-use changes in the L2A26 and L2A85 simulations, the models with dynamic vegetation simulate an increase in tree cover in response to climate and $\mathrm{CO}_{2}$ changes (Fig. 3, bottom).

The implementation of the harmonized scenarios in the land surface schemes is the first step in the interpretation of the land-use changes. The models are different not only in the way land-use change is interpreted in terms of land-cover changes but also in translating these land-cover changes into biogeophysical and biogeochemical characteristics of the land surface. These differences among the land surface schemes of the participating models are expected to yield differences in the simulated climatic response to land-use changes.

\section{Results and discussion}

To estimate statistical significance of the differences between the RCP and LUCID simulations, we used a Student's $t$ test that was modified to account for temporal autocorrelation in the time series (Findell et al. 2006; von Storch and Zwiers 1999). The $\mathrm{CO}_{2}$ forcings from anthropogenic emissions lead to strong trends in the simulated time series of climatic variables, especially in the RCP8.5 scenario. Therefore, the analyzed data of the last $30 \mathrm{yr}$ (2071-2100) were linearly detrended before the $t$ test was applied.

\section{a. Biogeophysical effects}

In response to the RCP scenarios, all models simulate an increase in global mean annual temperature (Fig. 4, top). The diversity among the models mainly reflects their different sensitivity to $\mathrm{CO}_{2}$ and other (e.g., aerosol) forcings, with EC-Earth and MPI-ESM-LR being the least sensitive $(0.5-0.6 \mathrm{~K}$ and $3.5-3.7 \mathrm{~K}$ increases between 2006 and 2100 for RCP2.6 and RCP8.5, respectively) and MIROC-ESM being the most sensitive (1.6 and $4.9 \mathrm{~K}$ for the RCP2.6 and RCP8.5 scenarios, respectively). The difference in global mean annual temperature between the RCP and LUCID simulations shown in dark and light colors, respectively (Fig. 4, top), is quite small and not statistically significant for any model because of substantial interannual variability simulated by ESMs. In addition, the imposed LULCC changes are quite small and dispersed (no strong coherent change in one region). As a result, the signal-to-noise ratio is too low to be pronounced on 

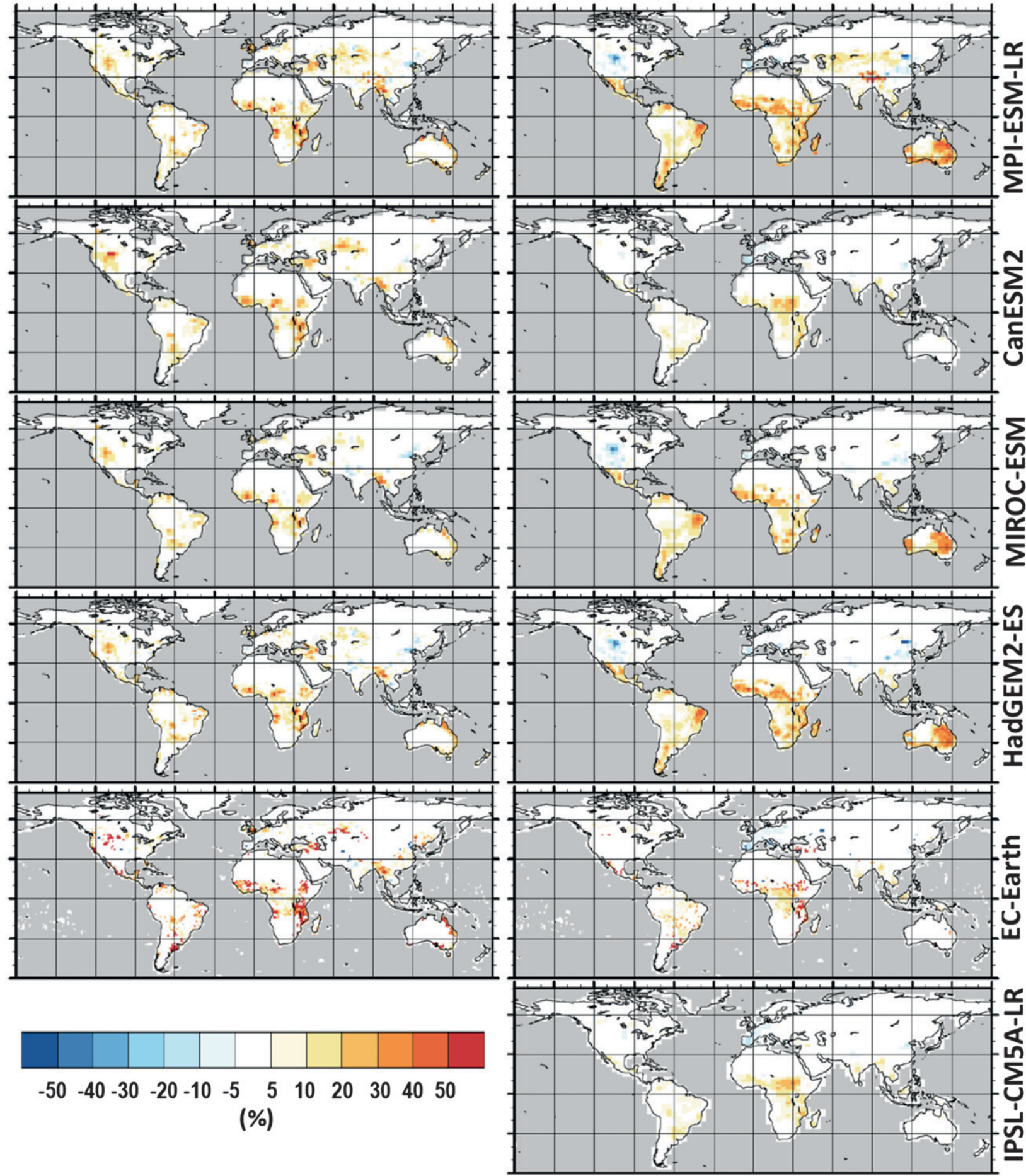

FIG. 2. Maps of changes in total crop and pasture fraction (\%) in the (left) RCP2.6 and (right) RCP8.5 simulations between 2006 and 2100 for (top)-(bottom) all LUCID-CMIP5 models. The fractions are specific for each model due to different interpretation of land-use change scenarios by land surface models.

the global scale. However, the LULCC effect is significant for two models-CanESM2 and HadGEM2-ESfor both RCP scenarios if the temperature is averaged over the regions with considerable land-use change (where LULCC over the period 2006-2100 exceeds $10 \%$ of gridcell area). For these regions, the CanESM2 model simulates an increase of $0.1 \mathrm{~K}$ in annual mean temperature averaged over 2070-2100 due to LULCC 


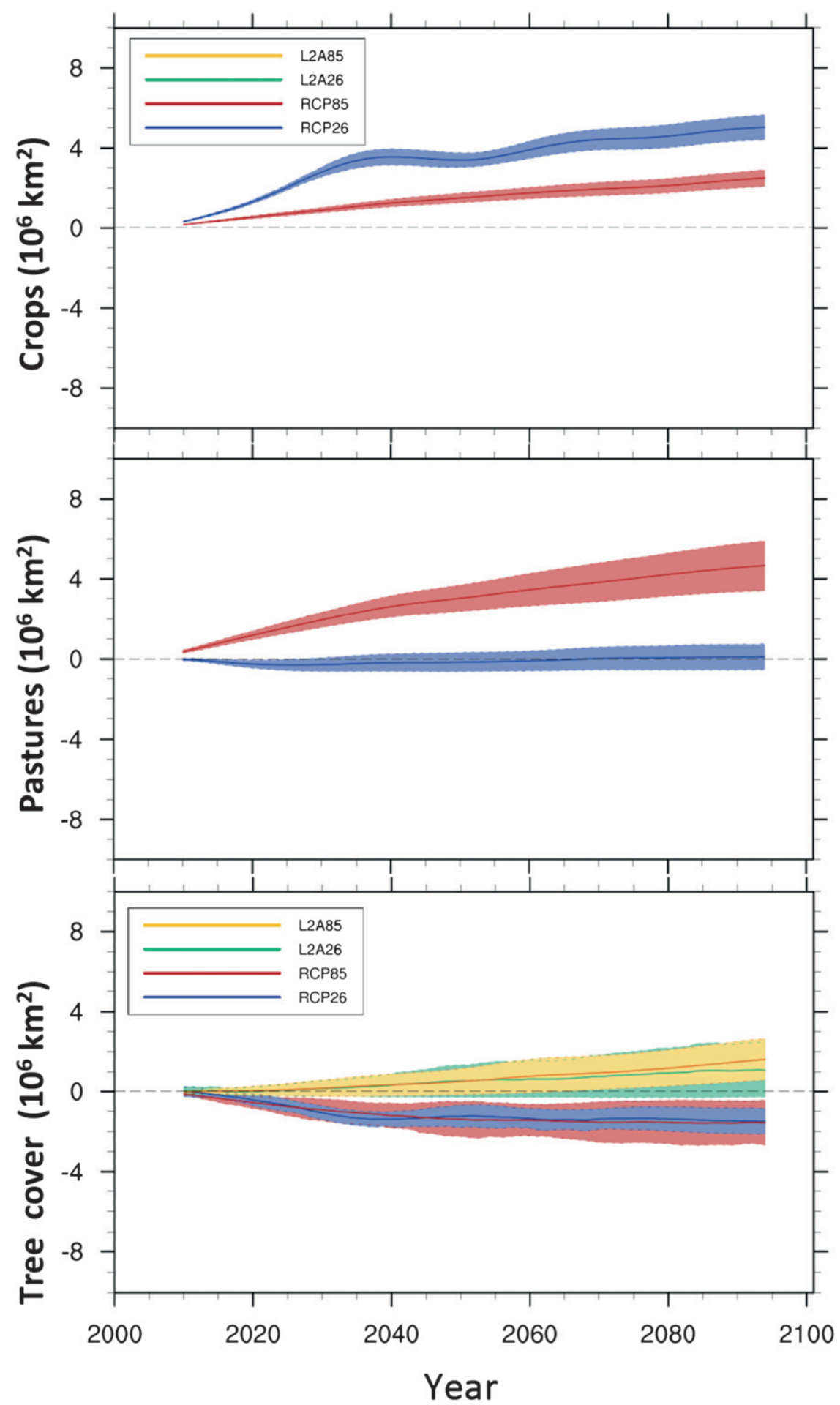

FIG. 3. Changes in global areas of (top) crops, (middle) pastures, and (bottom) tree cover between 2006 and $2100\left(10^{6} \mathrm{~km}^{2}\right)$. Shown is the 10-yr moving average over all models and ensemble members of the RCP and LUCID simulations. Bold lines are for mean values and dashed lines and shaded areas are for variability in fractions in ensemble simulations. Although land use was fixed in the LUCID simulations, small changes in crop and pasture areas occurred in models with vegetation dynamics. 


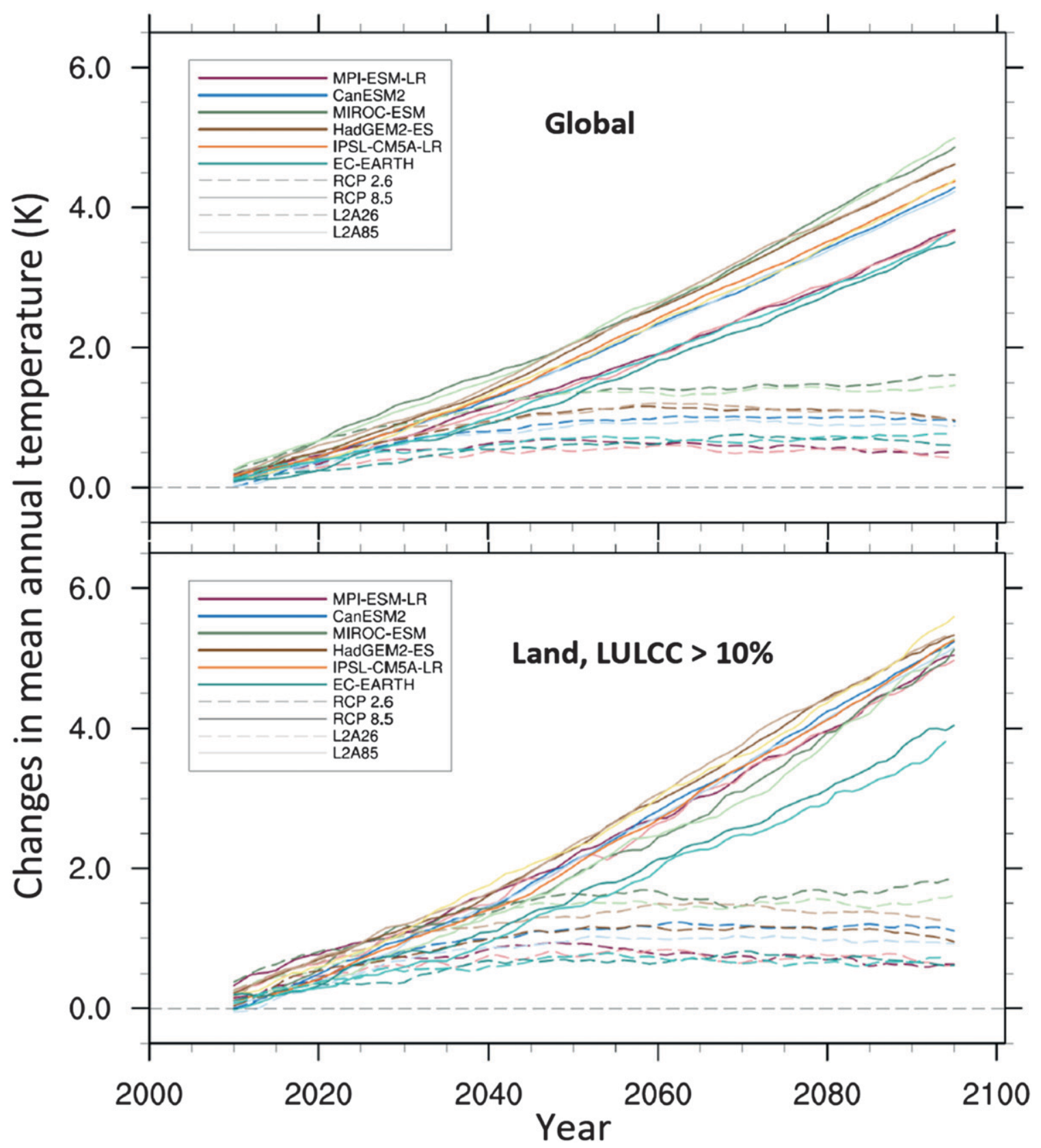

FIG. 4. The 10-yr moving average of changes relative to year 2006 in annual near-surface air temperature (K) averaged (top) for ensemble simulations globally and (bottom) for land grid cells where LULCC was $>10 \%$ of the cell area. Bold and dashed lines are for the RCP2.6 and RCP8.5 scenarios, respectively; and dark and light colors are for RCP and LUCID experiments, respectively.

and HadGEM2-ES, a decrease by $0.1 \mathrm{~K}$ (Fig. 4, bottom; Table 3). For the RCP8.5 scenario, MIROC-ESM shows an even stronger effect of land-cover changes $(-0.2 \mathrm{~K}$; Table 3$)$.

Spatial plots of significant changes in mean annual temperatures due to land-use changes are shown in Fig. 5. The MPI-ESM, HadGEM2-ES, and IPSL-CM5A models show little response, while CanESM2 shows a significant temperature increase in central Africa and MIROCESM shows an increase in South America in the RCP2.6 scenario. It is difficult to attribute temperature changes in individual small regions to LULCC in a strictly statistical sense. However, there is a strong indication for a causal link between the regional temperature signals discussed here and LULCC, because the statistically significant signal coincides spatially with regions of 
TABLE 3. Differences between RCP and LUCID simulations in annual mean climate characteristics averaged for land regions with LULCC $>10 \%$. Only statistically significant results $(p<0.05)$ are presented.

\begin{tabular}{|c|c|c|c|c|c|c|}
\hline Model & Scenario & $\begin{array}{c}\text { Surface air } \\
\text { temperature }(\mathrm{K})\end{array}$ & $\begin{array}{l}\text { Precipitation } \\
\left(\mathrm{mm} \mathrm{day}^{-1}\right)\end{array}$ & $\begin{array}{l}\text { Albedo } \\
(\times 100)\end{array}$ & $\begin{array}{l}\text { Available energy } \\
\qquad\left(\mathrm{W} \mathrm{m}^{-2}\right)\end{array}$ & $\begin{array}{l}\text { Latent heat flux } \\
\qquad\left(\mathrm{W} \mathrm{m}^{-2}\right)\end{array}$ \\
\hline \multirow[t]{2}{*}{ CanESM2 } & 2.6 & 0.11 & - & - & 0.5 & - \\
\hline & 8.5 & 0.10 & - & 0.03 & 0.6 & - \\
\hline EC-Earth & 2.6 & - & - & 0.33 & - & - \\
\hline EC-Earth & 8.5 & - & - & 0.32 & -1.4 & -0.5 \\
\hline \multirow[t]{2}{*}{ HadGEM2-ES } & 2.6 & -0.08 & -0.05 & 0.59 & -1.2 & -1.0 \\
\hline & 8.5 & -0.09 & -0.04 & 0.35 & -0.6 & - \\
\hline IPSL-CM5A-LR & 8.5 & - & - & 0.39 & -1.7 & - \\
\hline \multirow[t]{2}{*}{ MIROC-ESM } & 2.6 & - & - & 0.15 & - & -2.3 \\
\hline & 8.5 & -0.23 & - & 0.02 & - & -2.8 \\
\hline \multirow[t]{2}{*}{ MPI-ESM-LR } & 2.6 & - & -0.02 & 0.73 & -1.6 & -0.7 \\
\hline & 8.5 & - & - & 0.59 & -1.5 & 0.0 \\
\hline
\end{tabular}

strongest forcing and because the signal is in line with our knowledge of LULCC effects on local energy and water balance. For tropical and subtropical regions, the seasonality of the response of near surface air temperature for regions where LULCC exceeds $10 \%$ is small (Fig. B1).

Similar to temperature, precipitation changes due to LULCC (not shown) are only statistically significant in regions where LULCC exceeds 10\%. For the RCP2.6 scenario, annual mean precipitation in these regions is slightly reduced by $\sim(10-20) \mathrm{mm} \mathrm{yr}^{-1}$ in $2071-2100$ in MPI-ESM and HadGEM2-ES. A precipitation reduction of the same magnitude is significant for HadGEM2ES in the RCP8.5 scenario (Table 3).

The land-use changes in the analyzed RCP scenarios $\left[\sim\left(6-8 \times 10^{6}\right) \mathrm{km}^{2}\right]$ are about $10 \%-30 \%$ of the historical LULCC between 1500 and 2005 estimated by Hurtt et al. (2011): around $15.6 \times 10^{6} \mathrm{~km}^{2}$ of increase in cropland and $33.4 \times 10^{6} \mathrm{~km}^{2}$ of increase in pastures. A substantial part of historical LULCC occurred in the midlatitudes of Eurasia and North America, where the snow-masking effect of forests leads to a biogeophysical cooling effect of deforestation. The magnitude of this cooling differs among the models. ESMs of intermediate complexity suggest a global cooling effect of $0.1-0.3 \mathrm{~K}$ (Brovkin et al. 2006), while ESMs of full complexity reveal a less pronounced effect. Pongratz et al. (2010) found the cooling biogeophysical effect of LULCC over the last millennium to be 0.03 and $0.04 \mathrm{~K}$ averaged over the global and land, respectively. Lawrence et al. (2012) reported $0.1-\mathrm{K}$ cooling over the land for the historical period of 1850-2005. The scale of biogeophysical effects in RCPs scenarios found in our study is limited to $0.1-\mathrm{K}$ changes over land with LULCC $>10 \%$. This is consistent with a cooling of $0.1 \mathrm{~K}$ over agricultural regions found in the study by Pongratz et al. (2010). Therefore, regional climatic effects of future land-use changes could be comparable to the effects of the past land-use changes, when projected regional land-use changes are considerable. On a global scale, the biogeophysical effects of the RCP scenarios are smaller not only due to their lower magnitude in comparison to historical LULCC but also due to the dominant geographical location of RCP land-use changes in tropics and subtropics, where the snow-masking effect of forests does not play a role and negative feedbacks via cloud cover may be stronger. A large uncertainty in biogeophysical effects in the tropics is related to the effects of land use on evapotranspiration, air humidity, and clouds (Davin and de Noblet-Ducoudré 2010; Van der Molen et al. 2011), which vary strongly among ESMs.

In response to changes from natural ecosystems to crops or pastures, a fraction of tree and/or grass PFTs is replaced by agricultural vegetation, which in most cases has a higher albedo. These changes in land surface albedo for areas affected by LULCC are statistically significant for all models on an annual basis (Table 3). The difference in annual albedo between RCP and LUCID simulations by $2070-2100$ is most substantial in the MPIESM (0.007), HadGEM2-ES (0.006), and IPSL-CM5A (0.004) (Fig. 6). This increase in albedo in tropical regions leads to a substantial reduction in available energy (Table 3; Fig. B2a), defined as $Q_{S}(1-\alpha)+Q_{\mathrm{Ld}}$, where $Q_{S}$ is the shortwave radiation incident at the land surface, $\alpha$ is the surface albedo, and $Q_{\mathrm{Ld}}$ is the downwelling infrared radiation at the surface. This is not always reflected in temperature changes (Fig. 5). The seasonality of the albedo differences is small, presumably because seasonal changes in albedo in the tropics and subtropics are small in parameterizations of land surface processes in the models. This is different from seasonal changes in snow-covered regions in middle and high latitudes where the snow-masking effect of forests is important to consider (e.g., Bonan 2008). Land-use-induced changes 


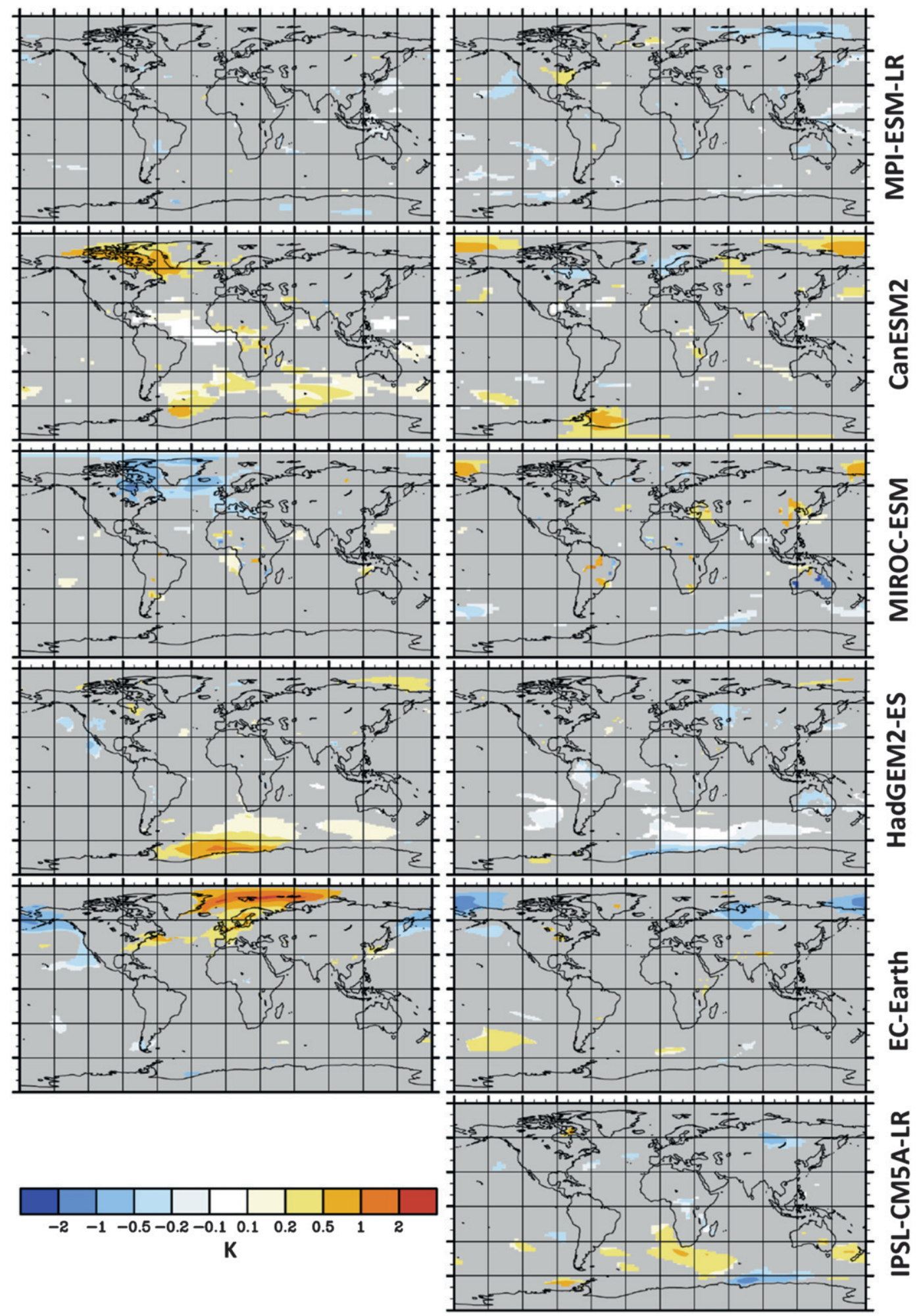

FIG. 5. Maps of difference in mean annual near-surface air temperature (K) between ensemble averages of the (top)-(bottom) RCP and LUCID simulations for (left) RCP2.6 and (right) RCP8.5 scenarios. The differences are averaged for years 2071-2100; only statistically significant changes $(p<0.05)$ are plotted. 


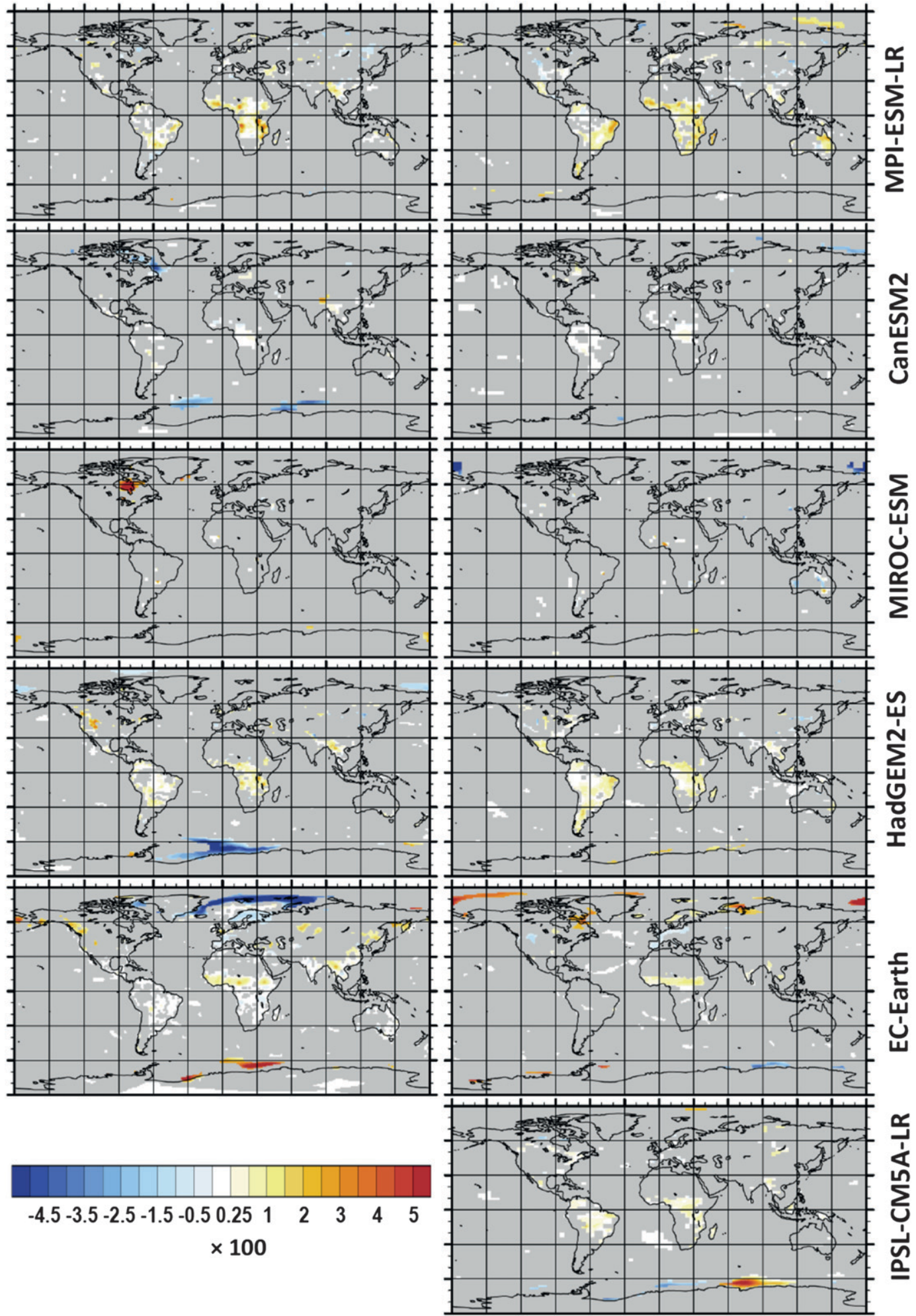

FIG. 6. As in Fig. 5, but for surface albedo $(\times 100)$. 


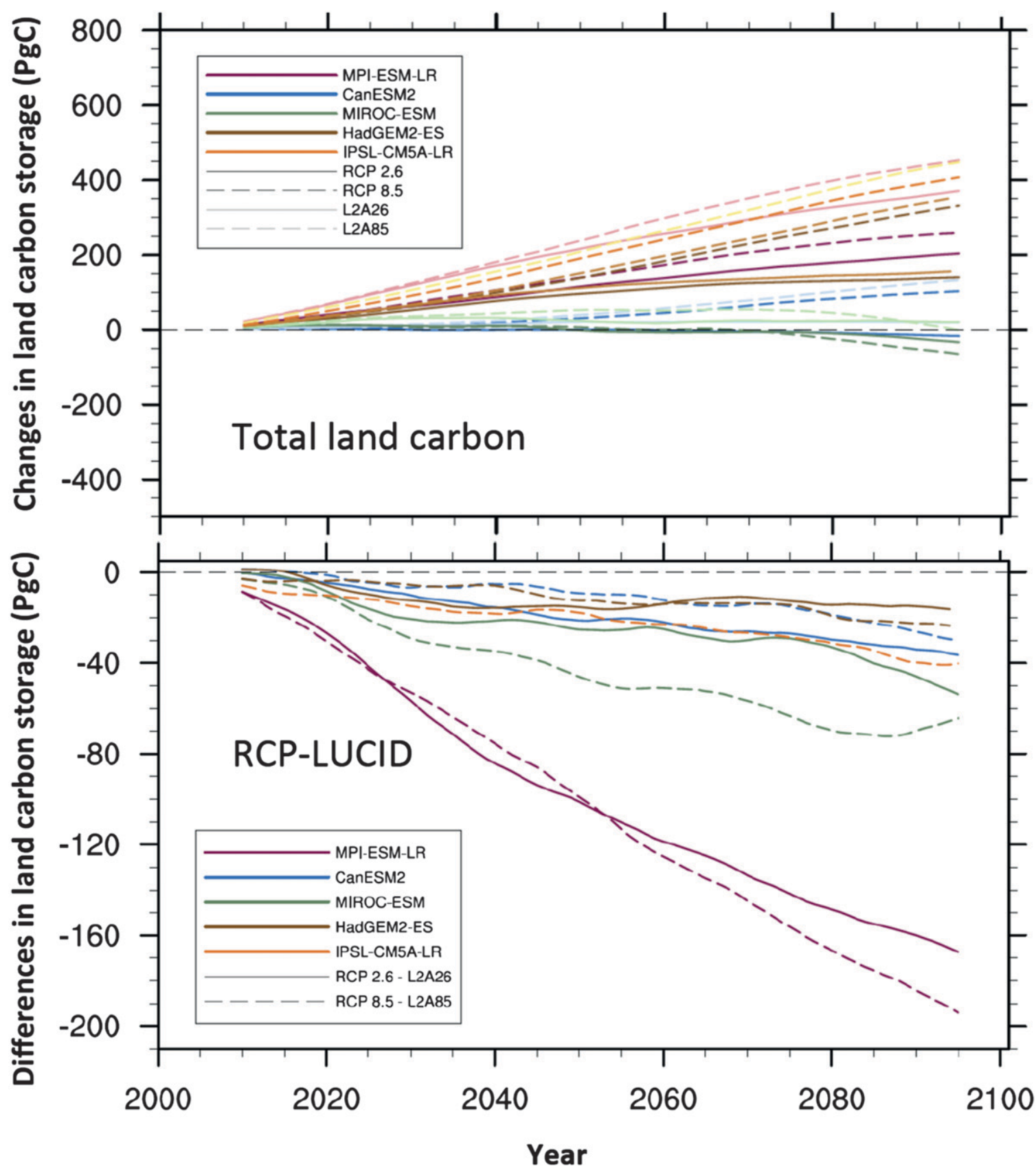

FIG. 7. The 10-yr moving average (top) of changes in total carbon storage (PgC) and (bottom) of differences in total land carbon storage between ensemble averages of the RCP and LUCID simulations. Bold and dashed lines are for the RCP2.6 and RCP8.5 scenarios, respectively.

in latent heat fluxes differ among the models. Most ESMs show a statistically significant decrease of latent heat flux for regions of considerable LULCC (Table 3).

\section{b. Changes in land carbon storages}

All models but EC-Earth simulated the land carbon cycle. A robust signal across models is the loss in global land carbon storage due to LULCC (Fig. 7). In nearly all simulations with and without LULCC, global terrestrial carbon stocks increase, although with substantial spread (Fig. 7, top). This increase can be explained by the effect of $\mathrm{CO}_{2}$ fertilization that tends to enhance the uptake of $\mathrm{CO}_{2}$ by terrestrial plants and that more than compensates the carbon losses associated with changes in temperature and precipitation (Arora et al. 2013; Friedlingstein et al. 2006). In the RCP scenarios, this 
TABLE 4. Estimated biogeochemical effect of land-use changes.

\begin{tabular}{lcccc}
\hline Model & RCP scenario & $\begin{array}{c}\text { Cumulative net } \\
\text { land-use emissions } \\
(\text { PgC; year 2100) }\end{array}$ & $\begin{array}{c}\text { Transient climate } \\
\text { sensitivity to emissions } \\
\left(\mathrm{K} \mathrm{TtC}^{-1 *} \text {; Gillett et al. 2013) }\right.\end{array}$ & $\begin{array}{c}\text { Estimated global annual } \\
\text { temperature increase } \\
(\mathrm{K} ; \text { year 2100) }\end{array}$ \\
\hline CanESM2 & 2.6 & 39 & 2.365 & 0.09 \\
HadGEM2-ES & 8.5 & 34 & 2.105 & 0.08 \\
IPSL-CM5A-LR & 2.6 & 19 & & 0.04 \\
MIROC-ESM & 8.5 & 25 & 1.585 & 0.05 \\
MPI-ESM-LR & 8.5 & 37 & 2.151 & 0.06 \\
& 2.6 & 65 & & 0.14 \\
& 8.5 & 62 & 1.604 & 0.13 \\
\end{tabular}

* Trillion tonnes of Carbon.

carbon gain is offset substantially by emissions resulting from clearing of natural vegetation (Fig. 7, top). Because the carbon cycle models in our study do not account for the limited availability of nitrogen $(\mathrm{N})$ and phosphorus (P) for the land ecosystems, they might overestimate the terrestrial carbon uptake in the future (Goll et al. 2012; Sokolov et al. 2008; Thornton et al. 2009; Zaehle et al. 2010). Accounting for $\mathrm{N}$ and $\mathrm{P}$ limitations could lead to a reduction of land carbon uptake in both RCP and LUCID simulations. However, since regional patterns of $\mathrm{N}$ and $\mathrm{P}$ limitations may not coincide with the LULCC patterns, it is difficult to estimate the significance of negligence of these limitations in the LUCID-CMIP5 experiments.

The difference between net land carbon storage in the RCP and LUCID simulations, as shown in Fig. 7 (bottom), is an estimate of net land-use emissions, which accounts for both carbon loss due to clearing of vegetation and carbon gain due to regrowth of vegetation after abandonment of management. The net losses range from $19 \mathrm{PgC}$ for HadGEM2-ES in RCP2.6 up to $205 \mathrm{PgC}$ for MPI-ESM in RCP8.5 (Table 4). Net landuse emissions have been quantified for the historical time period (e.g., Houghton et al. 2012; Pongratz et al. 2009) and the Special Report on Emission Scenarios (SRES) future scenarios (Sitch et al. 2005; Strassmann et al. 2008). These previous studies have revealed large uncertainties in emission quantification, on the order of $\pm 50 \%$, partly since the manner in which land-use change emissions are calculated varies widely amongst the different models and approaches (Arora and Boer 2010). These uncertainties arise from differences in implementation of LULCC data, inclusion or exclusion of specific land-use processes such as wood harvest (see Table 2), and different climate-carbon cycle representation in ESMs (Houghton et al. 2012). When the MPI model is excluded, the spread across models in LUCID-CMIP5 is on the same order of magnitude as these previously defined uncertainties.
The large loss in global carbon storage in both scenarios of the MPI-ESM (Table 4) is a result of an overestimation of initial carbon stocks in this model in the tropics and dry lands, so that carbon loss due to clearing is overestimated. Another reason of higher carbon losses is also the use of transition land-use matrices (Table 1). The MIROC-ESM, which also uses transitional matrices, is the model that yields the second-highest net land-use emissions. Consideration of transition land-use change matrices implies that rotational LULCC is accounted for instead of only net changes, which results in additional land-use change emissions above those resulting from net changes in crop and pasture area.

There are some robust features in the pattern of changes in carbon stocks. For instance, all models simulate a carbon loss in the tropical rain forests, especially over central Africa and eastern South America (Fig. 8). In these regions, strong LULCC coincides with high initial carbon stocks. Smaller regions show carbon gains, but the pattern varies across models. Increased carbon stocks by 2100 result partly from abandonment of agriculture (see, e.g., the RCP8.5 scenario in regions such as North America). In other cases a change from natural vegetation to managed land may increase carbon stocks (e.g., due to larger root mass under grasslands/pasture); the realism of the representation of such processes in ESMs is, however, limited.

Three of four models simulate a stronger carbon loss due to LULCC in RCP8.5 than in RCP2.6, despite almost identical forest cover changes in both scenarios. The likely reason is that in RCP8.5 more tropical rain forest with high carbon stock is cleared, while in $\mathrm{RCP} 2.6$ also clearing of natural vegetation in the extratropics occurs strongly for use in bioenergy. In the extratropics, lower carbon stocks prevail, and some of these areas are regrowing forest in RCP8.5. Note that another effect would tend to act in the opposite direction: almost all expansion of agricultural land in the 


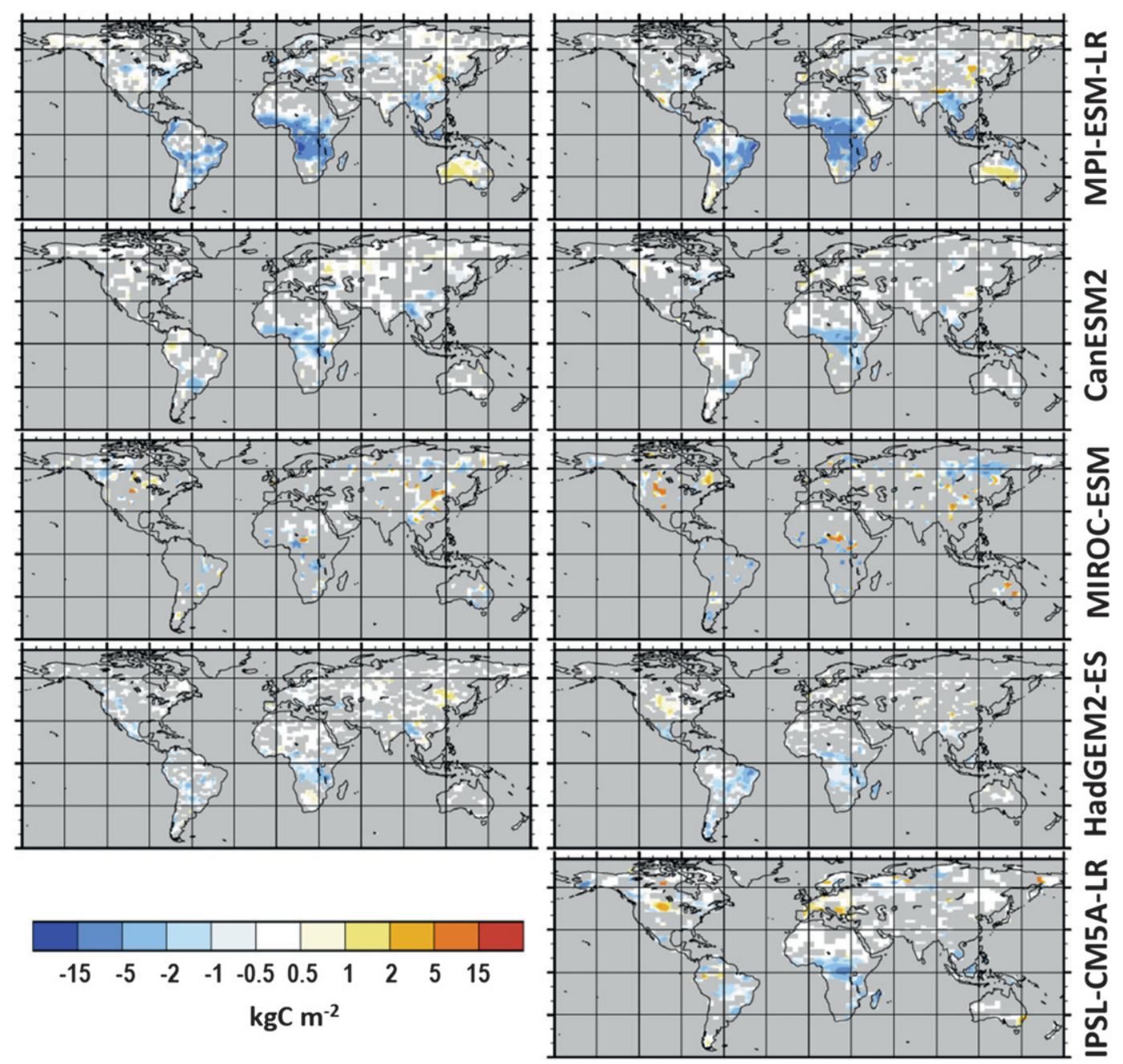

FIG. 8. Maps of difference in land carbon storage $\left(\mathrm{kgC} \mathrm{m}^{-2}\right)$ between ensemble averages of the RCP and LUCID simulations for (left) RCP2.6 and (right) RCP8.5 scenarios. The differences are averaged for years 2091-2100; only statistically significant changes $(p<0.05)$ are plotted.

RCP2.6 scenario is realized as expansion of croplands, while in the RCP8.5 scenario both croplands and pastures increase. Pasture, however, tends to be treated as natural grasslands in ESMs. Therefore, smaller carbon stock changes can be expected in the pasture-rich RCP8.5 scenario.

Lawrence et al. (2012) reported results from simulations of biogeochemical effects of LULCC in the RCP scenarios using the Community Climate System Model, version 4.0 (CCSM4.0). They have not performed simulations without land-use change as in the LUCID-CMIP5 protocol but estimated changes in total land carbon and land-use emissions from the RCP simulations. For RCP2.6 and RCP8.5, their model simulates a net release of 18.6 and $30.3 \mathrm{PgC}$ during 2006-2100, respectively, from land ecosystems to the atmosphere. Comparing with the response of LUCID-CMIP5 models (Fig. 7; Table 4), the CCSM4 results are at the low end.

The L2A85 and L2A26 simulations were performed with prescribed atmospheric $\mathrm{CO}_{2}$ concentrations; therefore, they do not provide a direct estimate of biogeochemical effects of LULCC emissions. Gillett et al. (2013) calculate transient response to cumulative emissions [TRCE; $\mathrm{K}(\mathrm{EgC})^{-1}, 1$ exagram of carbon = $10^{18} \mathrm{gC}$, which is defined as the ratio of global mean warming to cumulative emissions at $\mathrm{CO}_{2}$ doubling using results from $1 \% \mathrm{yr}^{-1} \mathrm{CO}_{2}$ increase simulations for 12 participating CMIP5 models. Here, we multiply net landuse change emissions (Fig. 7) by their corresponding model's TRCE to translate them into equivalent temperature changes. The methodology provides coarse estimates but nevertheless gives a first-order estimate 
of the temperature effect associated with the biogeochemical pathway of land-use change. For RCP8.5, the changes are below $0.1 \mathrm{~K}$ for all models but the MPI-ESM (Table 4), which, as mentioned above, overestimates the carbon release due to land-use change. For RCP2.6, the effect is more pronounced because of lower background $\mathrm{CO}_{2}$ concentration. For HadGEM2-ES and CanESM2, the temperature changes are below $0.1 \mathrm{~K}$, but MIROCESM and MPI-ESM yield more substantial changes of 0.14 and $0.33 \mathrm{~K}$, respectively. This suggests that the biogeochemical effect of land-use changes is more substantial in absolute and relative terms for the climate change mitigation scenario.

\section{Summary and conclusions}

The LUCID-CMIP5 experiments were designed to evaluate climatic effects of future land-use change scenarios using ESMs participating in the CMIP5. The analysis here was limited to experiments with prescribed atmospheric $\mathrm{CO}_{2}$ concentrations. On the global scale, simulated biogeophysical effects of landuse changes projected in the RCP2.6 and RCP8.5 scenarios were not significant. However, these effects were significant for regions with land-use changes exceeding $10 \%$. Three out of six participating models-MIROCESM, HadGEM2-ES, and CanESM2-revealed small $(-0.2,-0.1$, and $0.1 \mathrm{~K}$, respectively) but statistically significant changes in regional mean annual surface air temperature. Changes in land surface albedo, available energy, and latent heat fluxes were small but significant in most ESMs for regions with considerable land-use changes.

The small climatic effects of LULCC in the RCP scenarios is likely explained by the relatively small scale of land-use changes and their dominance in the tropical and subtropical regions where the difference between biogeophysical parameters of land-cover types is less pronounced than in middle and high latitudes. This conclusion on the small scale of biogeophysical effects is valid only for the studied RCP scenarios. For example, changes in land cover of a larger scale located in regions with seasonal snow cover would likely lead to larger climatic effects, although the role of snow cover in amplifying the LULCC effect is going to decline in warmer climate (Pitman et al. 2011). This also points to the importance of a skillful design of the spatial patterns of LULCC in the development of the scenarios underlying the RCPs. The current approach in the RCP framework is to develop an ensemble of socioeconomic and emissions scenarios to match a previously identified pathway of greenhouse gas concentrations (Moss et al. 2010). However, various scenarios with very different regional changes in LULCC and industrial activity may be consistent with the same RCP. While the spatial pattern of forcing is less relevant for the well-mixed greenhouse gases, the regional climate response is sensitive toward the spatial pattern of LULCC. These regional response patterns are as important as global changes for the scientific community assessing impacts, adaptation, and vulnerability of natural and social systems to climate change.

In both the RCP2.6 and RCP8.5 scenarios, land-use change leads to a reduction in land carbon storage. The difference between experiments with and without landuse change ranges between 19 and $205 \mathrm{PgC}$, with the high number generated by MPI-ESM, which is likely to overestimate the carbon release because of a too-high initial carbon stock. The spread in the LULCC-induced $\mathrm{CO}_{2}$ emissions is due to differences in parameterizations of land carbon cycle processes such as $\mathrm{CO}_{2}$ fertilization, regrowth, initial carbon storage, and wood harvest implementation. The spread across ESMs in regards to future carbon cycle changes is dominated by the uncertainty in land carbon uptake (Arora et al. 2013; Jones et al. 2013). Jones et al. (2013) discuss that model representation of land-use change is an important contribution to future land carbon spread between models. The LUCID-CMIP5 simulations help quantify this spread, although with some limitations. For example, accounting for the $\mathrm{N}$ and $\mathrm{P}$ limitations could potentially reduce the LULCC effect on the land carbon changes, but the uncertainty associated with the quantification of $\mathrm{N}$ and $\mathrm{P}$ turnover is still too large to make a firm conclusion on its significance for the carbon flux associated with LULCC.

The LUCID-CMIP5 experiments demonstrated different responses of ESMs to the land-use forcing, which is in line with findings of previous intercomparison experiments in the LUCID framework (e.g., de NobletDucoudré et al. 2012; Pitman et al. 2009). The diversity of the model responses is caused by a number of reasons. First, the models varied in interpretation of the harmonized land-use change scenarios (crops, pastures, and primary and secondary land) in terms of land cover (PFTs) used in ESMs. Some ESMs (HadGEM2-ES, MIROC-ESM, and MPI-ESM) include modules of vegetation dynamics, which makes allocation of land to cropland and pasture dependent on climate changes. Thus, the manner in which land-use changes are interpreted in models with dynamic vegetation are more sophisticated in comparison with models with prescribed land cover and have a larger number of degrees of freedom (Reick et al. 2013). Second, ESMs treat changes in land cover using different parameterizations of land surface processes. For example, models with significant albedo response (HadGEM2-ES, IPSL-CM5A, 
MPI-ESM, and EC-Earth) tend to cool the land surface because of land-use changes, at least in the RCP2.6 scenario, while models with smaller albedo changes (MIROC-ESM and CanESM2) show an increase in the land temperature for the same scenario. A way forward to reduce uncertainty in projections of climate response to land-use changes is now under intensive debate in the land surface modeling community (Pielke et al. 2011).

Although the model responses to the forcing varied substantially, we can draw several robust conclusions from the experiments analyzed here. First, the fossil fuel forcing dominates over the land-use forcing in the RCP projections in the twenty-first century. This is in contrast to the historical period when the land-use forcing, especially via $\mathrm{CO}_{2}$ emissions due to land use, was of a similar order of magnitude as the fossil fuel forcing. Second, for low $\mathrm{CO}_{2}$ emission scenarios, such as RCP2.6, the relative role of land-use forcing is significant, essentially through the biogeochemical effect. The diagnosed global biogeochemical effects are on the order of $0.1 \mathrm{~K}$, and some models suggest an increase in global temperature in the range of $0.1-0.3 \mathrm{~K}$, which is comparable with $0.5-1.6-\mathrm{K}$ warming in the twenty-first century simulated for the RCP2.6 scenario. Besides, this scenario involves land-use changes for biofuel crop production. Future investigation of the climatic effects of land-use changes, including those with a focus on the biogeochemical pathway through the use of specifiedemissions simulations, are essential for assessment of climate mitigation scenarios and regional climate change adaptation.

Acknowledgments. We acknowledge the World Climate Research Programme Working Group on Coupled Modelling, which is responsible for CMIP, and we thank the climate modeling groups for producing and making available their model output. We thank Karl Taylor and Charles Doutriaux for help with setting up the CMOR tables for the LUCID-CMIP5 experiments. We appreciate a support by the staff of the German Climate Computing Center (DKRZ), in particular by Stephanie Legutke and Estanislao Gonzalez, in performing the LUCID-CMIP5 simulations and in making the model results available via DKRZ ESG gateway. We thank Andy Pitman and an anonymous reviewer for providing constructive and helpful comments on the manuscript. CDJ was supported by the Joint DECC/Defra Met Office Hadley Centre Climate Programme (GA01101). EK was supported by the Environmental Research and Technology Development Fund (S-5, S-10) of the Ministry of the Environment, Japan. PF and FP were supported by the EU-FP7 COMBINE project (Grant 226520).

\section{APPENDIX A}

\section{Model Descriptions}

\section{a. CCCma CanESM2}

CanESM2 has evolved from the First Generation Canadian Earth System Model (CanESM1) (Arora et al. 2009; Christian et al. 2010) of the Canadian Centre for Climate Modelling and Analysis (CCCma) and described in Arora et al. (2011). The horizontal resolution of the atmospheric model is about $2.8^{\circ}$, while the physical ocean horizontal resolution is approximately $1.41^{\circ}$ (longitude) $\times 0.94^{\circ}$ (latitude) .

Terrestrial ecosystem processes are modeled using the Canadian Terrestrial Ecosystem Model (CTEM), which simulates carbon in three live vegetation pools (leaves, stem, and root) and two dead pools (litter and soil organic carbon) for nine plant functional types (PFTs): needleleaf evergreen and deciduous trees, broadleaf evergreen and cold and dry deciduous trees, and $\mathrm{C}_{3}$ and $\mathrm{C}_{4}$ crops and grasses (Arora and Boer 2010).

CanESM2 includes the changes in crop area from the harmonized land-use change scenarios following the linear approach of Arora and Boer (2010). In this approach the fractional coverage of herbaceous and woody PFTs is reduced by an amount proportional to their existing coverage in order to allow an increase in crop fraction. If the crop fraction decreases, the fractional coverage of natural PFTs is increased while ensuring that these PFTs can potentially exist in a grid cell. The effect of changes in pasture area on land cover is not taken into account. A simple crop model is used over the cropland fraction of a grid cell. That determines harvest based on temperature or phenological criteria. This typically leads to one annual crop cycle in high- to midlatitude regions and multiple crop cycles in tropical regions. Harvesting ensures that vegetation biomass does not keep increasing on croplands as $\mathrm{CO}_{2}$ increases and prevents croplands from sequestering carbon like forests.

\section{b. EC-Earth}

EC-Earth is a fully coupled atmosphere-ocean GCM (AOGCM; Hazeleger et al. 2012; Hazeleger et al. 2010), consisting of NEMO2 for the ocean; the Louvain-laNeuve Sea-Ice Model, version 2 (LIM2); and the atmosphere module of EC-Earth resembling the Integrated Forecast System (IFS) from early 2006 (cycle CY31) of the numerical weather prediction model of the European Center for Medium-Range Weather Forecasts (ECMWF), with some updates (land surface and convection scheme) from cycle CY33. Model simulations are carried out at 
a resolution of T159L62 $\left(\sim 1.1^{\circ}\right)$, with the ocean model resolution of $1^{\circ}$ (Hazeleger et al. 2012).

The land surface scheme Hydrology Tiled ECMWF Scheme for Surface Exchanges over Land (HTESSEL) is based on the version described by van den Hurk et al. $(2003,2000)$ with a revised snow scheme (Balsamo et al. 2009; Dutra et al. 2010). For the calculation of surface fluxes, each grid cell is subdivided into tiles of bare soil, high (trees) and low (grasses and shrubs) vegetation, intercepted water, and snow. Total fluxes are calculated as weighted average of individual surface energy balances per tile based on the resistance approach, where aerodynamic and surface resistances account for the transfer efficiency of heat and water vapor over a vertical temperature and humidity gradient.

EC-Earth uses the Global Land Cover Characteristics database version 2.0 at $\sim 1-\mathrm{km}$ resolution as base map, which distinguishes 15 vegetation types in the land surface scheme. Their respective cover fractions are modified according to the time series of the harmonized land-use change scenario fractions as follows: At the resolution of the scenario data of $0.5^{\circ}$, the crop fraction is synchronized with the value given by Hurtt et al. (2011). All noncrop vegetation in a cell is proportionally adjusted. If a cell transforms from crop to natural vegetation and no information on natural vegetation is available (e.g., if crop area equals $100 \%$ ), information from a potential vegetation map (Klein Goldewijk 2001) is used for that grid cell to determine which vegetation type might typically grow. In a second step, information of pasture extents is accounted for. Since grazing can take place both over naturally vegetated areas as well as anthropogenically modified areas, forest is only reduced by proportional replacement by grasses if the sum of all low vegetation (both natural and anthropogenic vegetation types) is less than the pasture fraction given by Hurtt et al. (2011). The new land-cover map is interpolated to the coarser resolution of EC-Earth and only dominant high and low vegetation types per grid cell are kept.

\section{c. IPSL-CM5A-LR}

The IPSL-CM5A (Dufresne et al. 2013) is the newgeneration Earth system model developed at L'Institut Pierre Simon Laplace. The atmosphere and land models of IPSL-CM5ACM5 are updated versions of those used in IPSL-CM4 (Marti et al. 2010): namely, the Laboratoire de Météorologie Dynamique atmospheric general circulation model with zoom capability (LMDZ) (Hourdin et al. 2006) and the Organizing Carbon and Hydrology in Dynamic Ecosystems (ORCHIDEE) land surface model (Krinner et al. 2005). The atmospheric and land components use the same regular horizontal grid with $96 \times 96$ points, representing a resolution of $3.6^{\circ} \times 1.8^{\circ}$, while the atmosphere has 39 vertical levels. The oceanic component is NEMO, version 3.2 (Madec 2008), with a horizontal resolution of $2^{\circ}-0.5^{\circ}$ and 31 vertical levels.

The land component ORCHIDEE (Krinner et al. 2005) simulates, with a daily time step, processes of photosynthesis, carbon allocation, litter decomposition, soil carbon dynamics, maintenance and growth respiration, and phenology for 13 different plant functional types.

In the IPSL-CM5A, the identical land-cover map is used for both the historical and the future period. It is based on an observed present-day land-cover map (Loveland et al. 2000) that includes natural and anthropogenic vegetation types. The land-use changes are implemented in the following way: First, the area covered by crops, per year and per grid cell, is set to the value provided by the harmonized land-use change scenario. The expansion of this crop area proportionally occurs at the expense of all natural vegetation types. This means the percent by which natural grasses and tree areas are reduced is the same for all PFTs. Reciprocally, a reduction of the anthropogenic area implies a proportional increase of all natural vegetation types existing in any given grid cell. If no information is available on the natural vegetation distribution at a specific location (i.e., $100 \%$ anthropogenic types on the original land-cover map used), then the model algorithm searches for the nearest point that has natural vegetation and introduces those vegetation types. The desert extent is kept unchanged from preindustrial times until the end of the twenty-first century, with one exception: desert is reduced if the anthropogenic area is larger than the natural vegetation part of the grid cell. After this first step where the change in crop area has been handled, grazing is introduced as follows: if the pasture area from the land-use scenario is lower than the area covered with grasses and shrubs, nothing is changed. If the pasture area is larger than the area covered with grasses and shrubs, a part of the forested area is replaced by grassland.

\section{d. Japan Agency for Marine-Earth Science and Technology (JAMSTEC) MIROC-ESM}

The MIROC-ESM (Watanabe et al. 2011) is based on the global climate model MIROC. The MIROC-AGCM has a spectral dynamical core and uses a flux-form semiLagrangian scheme for the tracer advection. The grid resolution is approximately $2.81^{\circ}$ with 80 vertical levels between the surface and about $0.003 \mathrm{hPa}$. The physical ocean component of MIROC-ESM [Center for Climate System Research (CCSR) Ocean Component Model (COCO), version 3.4] has longitudinal grid spacing of 

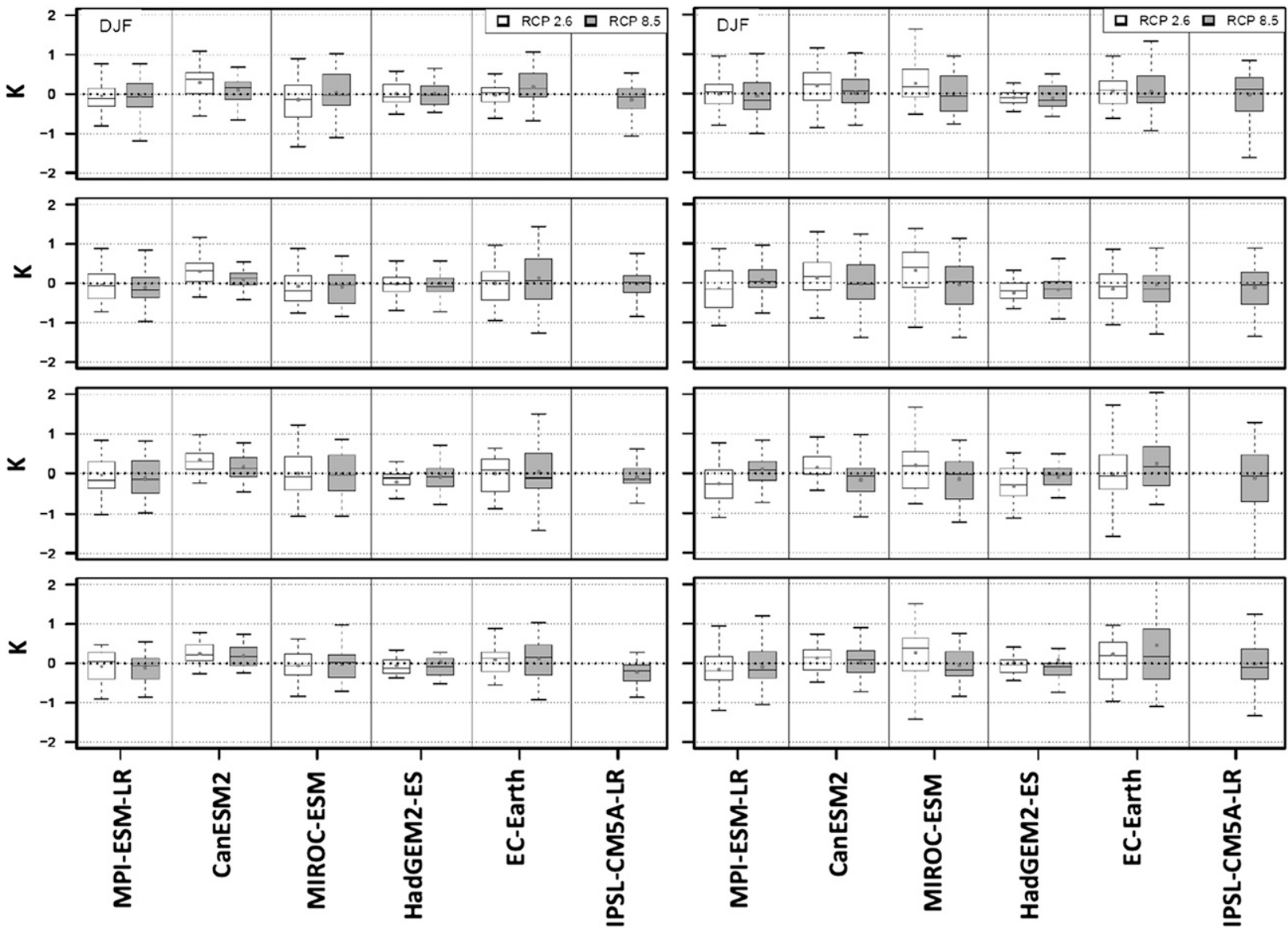

FIG. B1. Box-and-whisker plots for differences in mean seasonal near-surface air temperature (K) between ensemble averages of the RCP and LUCID simulations for RCP2.6 (open box) and RCP8.5 (filled box) scenarios and for land grid cells where LULCC was $>10 \%$ of the cell area. The plots are based on the data for the years 2071-2100 averaged for (left) Africa, (middle) South America, and (right) Australia. The bottom and top of boxes are for the 25th and 75th percentiles and the lower (upper) whiskers are for 1.5-interquartile ranges of lower (upper) quartiles. In the box, the black line is the median and the dot is the mean. The seasons (top)-(bottom) are December-February (DJF), March-May (MAM), June-August (JJA), and September-November (SON).

about $1.4^{\circ}$, while the latitudinal grid intervals gradually vary from $0.5^{\circ}$ at the equator to $1.7^{\circ}$ near the NorthSouth Pole with 44 levels in the vertical.

A terrestrial ecosystem component with dynamic vegetation Spatially Explicit Individual-Based Dynamic Global Vegetation Model (SEIB-DGVM; Sato et al. 2007) adopts an individual-based simulation scheme that explicitly captures light competition among trees. Vegetation is classified into 13 PFTs, consisting of 11 tree PFTs and 2 grass PFTs. The dynamics of the two soil organic carbon pools (fast and slow decomposing) is based on the Rothamsted Carbon (RothC) model (Coleman et al. 1997).

In the MIROC-ESM, each land grid cell is subdivided in 900 cells of the terrestrial ecosystem model. The number of these cells assigned as cropland, pasture, and urban land is defined according to the harmonized landuse fraction. Cells for primary and secondary land are simulated with a dynamic vegetation module, and the fraction of grassland and forest is changing with time. In cells assigned as secondary land, the vegetation dynamics module simulates regrowth of trees and grasses after the abandonment of cropland and pasture. The conversion of land-use types follows a simple rule of cell arrangement within the grid.

\section{e. MPI-ESM-LR}

The Earth system model developed at the Max Planck Institute for Meteorology in Hamburg, Germany (MPIESM), includes the atmospheric model ECHAM6 in T63 $\left(1.9^{\circ} \times 1.9^{\circ}\right)$ resolution with 47 vertical levels described by Stevens et al. (2013), the oceanic model MPI$\mathrm{OM}$ at approximately $1.6^{\circ}$ resolution with 40 vertical layers (Jungclaus et al. 2006), and the land surface model Jena Scheme for Biosphere-Atmosphere Coupling in Hamburg (JSBACH; Raddatz et al. 2007) sharing the 

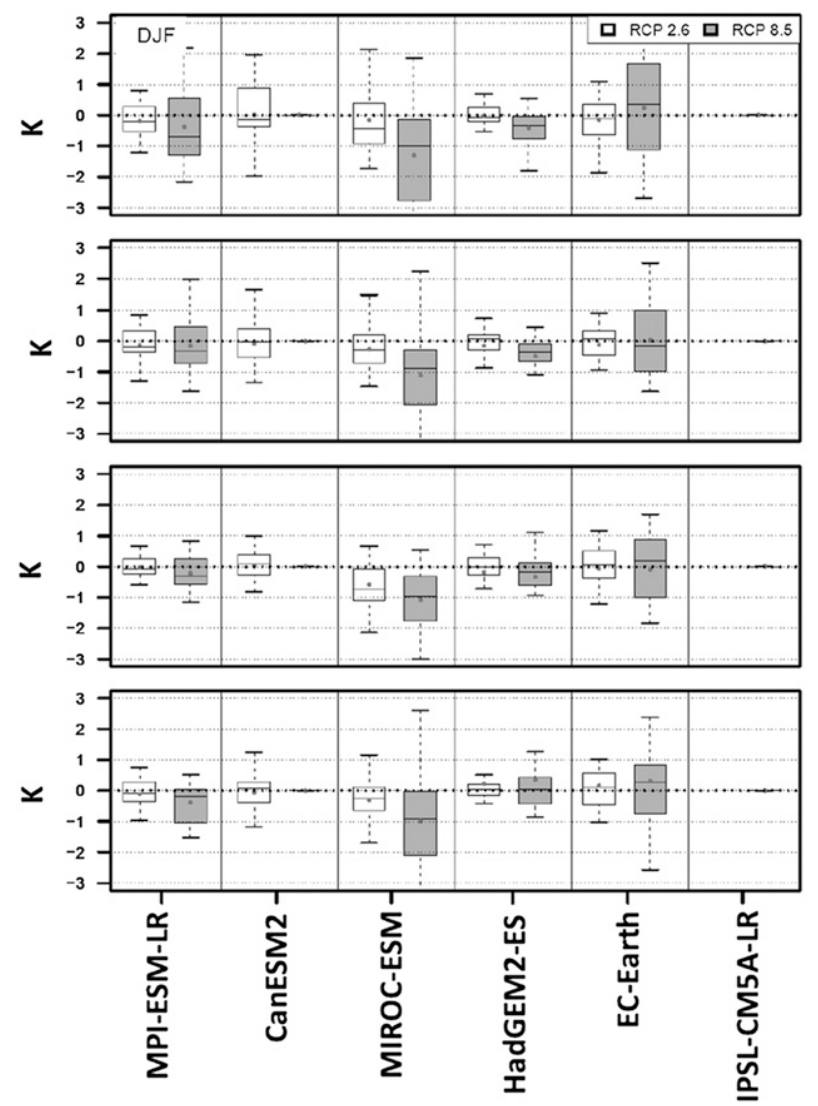

FIG. B1. (Continued)

horizontal grid of the atmospheric model. This grid setup is a low-resolution version (LR) of the model used for centennial-time-scale simulations in CMIP5. A detailed description of the model and an evaluation of the model performance regarding temperature and precipitation fields is given by Giorgetta et al. (2013).

The land surface model of MPI-ESM, JSBACH (Raddatz et al. 2007), simulates fluxes of energy, water, momentum, and $\mathrm{CO}_{2}$ between land and atmosphere. Each land grid cell is divided into tiles covered with up to 12 plant functional types. A module for vegetation dynamics (Brovkin et al. 2009) is based on the assumption that competition between different PFTs is determined by their relative competitiveness expressed in annual net primary productivity (NPP), as well as natural and disturbance-driven mortality (fire and wind disturbance).

The MPI-ESM combines primary and secondary land into one vegetation class (natural vegetation) and considers transitions between three vegetation classes (natural vegetation, croplands, and pastures). Allocation of new croplands and pastures follows several simple rules (Reick et al. 2013). The demand for pastures is firstly covered by natural grasslands and, only if there is no grassland area left, areas of woody PFTs (trees and shrubs) are allocated to pastures. This rule assumes that using natural grassland as a pasture is an easier way for farmers to manage the land. The demand for croplands is equally shared among all natural PFTs in the land grid cell. MPI-ESM includes a dynamic vegetation model (Brovkin et al. 2009), and the fraction of natural vegetation, such as grassland and forest, is changing with time. This can potentially lead to some changes in cropland and pastures areas when the regional climate becomes unsuitable for any natural vegetation (Reick et al. 2013). Unlike the other models, the MPI-ESM also uses information from the harmonized protocol on wood harvest.

\section{f. Met Office HadGEM2-ES}

HadGEM2-ES (Collins et al. 2011) couples interactive ocean biogeochemistry, terrestrial biogeochemistry and dust, and interactive atmospheric chemistry and aerosol components into an update of the physical model HadGEM1 (Johns et al. 2006). The physical model contains a 40 -level $1^{\circ} \times 1^{\circ}$ ocean, moving to $13^{\circ}$ at the equator, and a 38 -level $1.875^{\circ} \times 1.25^{\circ}$ atmosphere (Martin et al. 2011). HadGEM2-ES has been set up and used to perform CMIP5 simulations as described by Jones et al. (2011).

The terrestrial carbon cycle is represented by the Met Office Surface Exchange Scheme, version 2 (MOSES2) land surface scheme (Essery et al. 2003), which simulates exchange of water, energy and carbon between the land surface and the atmosphere, and the Top-Down Representation of Interactive Foliage and Flora Including Dynamics (TRIFFID) dynamic global vegetation model (Cox 2001), which simulates the coverage and competition between five plant functional types (broadleaf tree, needleleaf tree, and $\mathrm{C}_{3}$ and $\mathrm{C}_{4}$ grass and shrub) and four nonvegetated surface types (bare soil, urban, lakes, and land ice). The soil carbon component has been updated based on the four-pool Roth-C soil carbon model (Jones et al. 2005).

In the HadGEM2-ES, the crop and pasture fractions from the harmonized land-use change scenarios are added together and interpreted as a fraction of agricultural land. This agricultural fraction is added as a mask on top of simulated dynamic vegetation to prevent woody vegetation within the agricultural area. Grassland is preferentially used for agriculture. For example, if an area would naturally have $50 \%$ tree and $50 \%$ grass but the agriculture fraction is $70 \%$, then the tree fraction is limited to $30 \%$. The vegetation dynamics module simulates growth of grass or not (i.e., allocate bare soil) in the remaining $30 \%$ area depending on the prevailing climate. When the agriculture mask increases, natural vegetation is removed. However, when agricultural area 
(a)
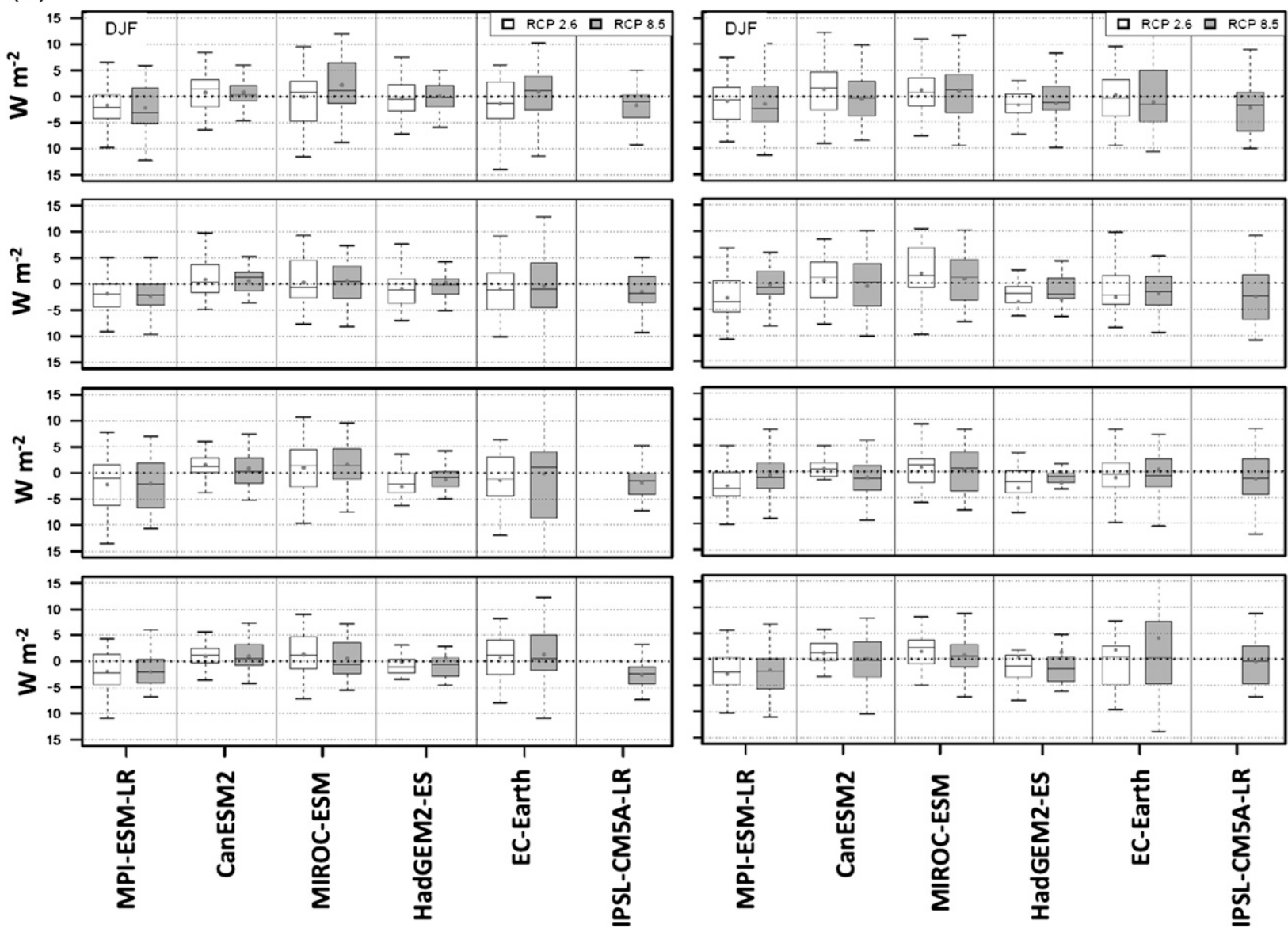

놈

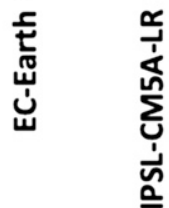

FIG. B2. (a) Box-and-whisker plots for differences in seasonal available energy $\left(\mathrm{W} \mathrm{m}^{-2}\right)$ between ensemble averages of the RCP and LUCID simulations for RCP2.6 (open box) and RCP8.5 (filled box) scenarios and for land grid cells where LULCC was $>10 \%$ of the cell area. The plots are based on the data for years 2071-2100 averaged for (left) Africa and (right) South America. The dots in the boxes show the mean. Seasons are as in Fig. B1. (b) As in (a), but for surface upward latent heat flux $\left(\mathrm{W} \mathrm{m}^{-2}\right)$.

is reduced, the vegetation dynamics module simulates regrowth of trees and grasses in that place, provided the climate is suitable.

\section{APPENDIX B}

\section{Regional Analysis}

The temperature response to changes in LULCC is most pronounced for Australia for the RCP8.5 scenario characterized by a strong increase in pasture in this region (Fig. B1). All models that explicitly account for the pasture changes (MPI-ESM, MIROC-ESM, and HadGEM2-ES) show a decrease in temperature over LULCC $>10 \%$ regions almost in all seasons with the strongest cooling of $1 \mathrm{~K}$ simulated by the MIROC-ESM. The model response depends on the manner in which pasture changes are interpreted in the models. A conversion from the shrubby-type natural vegetation to pasture (rangeland) in Australia may not be followed by a decrease in shrub cover, as is assumed in most of the ESMs, which in most cases treat pastures as grasslands.

Decrease in the latent heat flux for areas with LULCC exceeding $10 \%$ in South America is pronounced in the MPI-ESM, HadGEM2-ES, and IPSL-CM5A (Fig. B2b). These are models with a significant increase in albedo (Fig. 6) and reduction in available energy (Fig. B2a); therefore, reduction in latent heat flux does not cause an increase in temperature. In contrast, the MIROC-ESM in RCP2.6 has almost no reduction in latent heat flux in South America in all seasons but March-May (MAM), while it simulates an increase in temperature by $0.1 \mathrm{~K}$. Differences in albedo in response to land-cover changes among models can lead to these opposite climatic effects, although their magnitude remains small. 
(b)
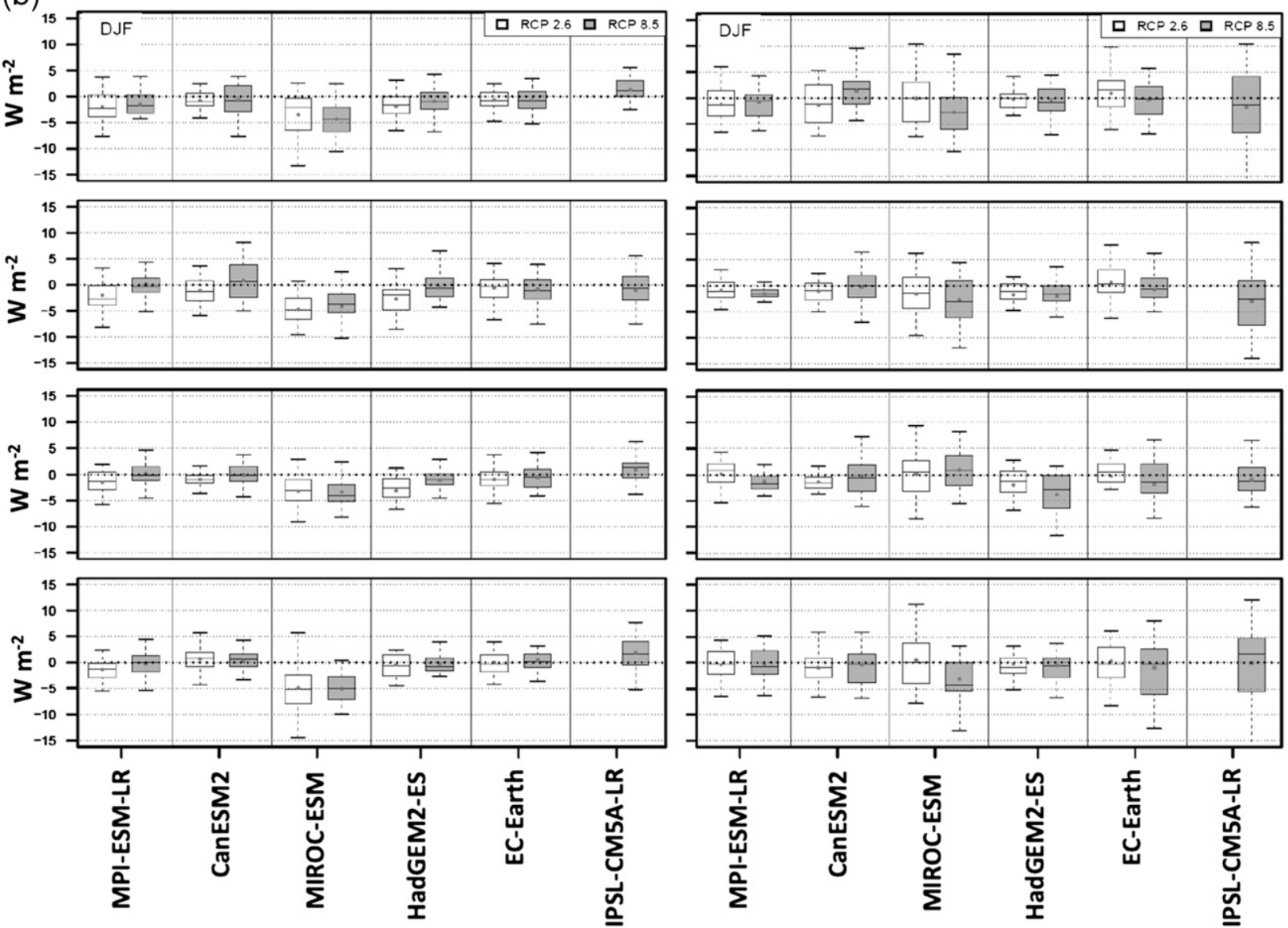

FIG. B2. (Continued)

\section{REFERENCES}

Arora, V. K., and G. J. Boer, 2010: Uncertainties in the 20th century carbon budget associated with land use change. Global Change Biol., 16, 3327-3348.

— , and Coauthors, 2009: The effect of terrestrial photosynthesis down regulation on the twentieth-century carbon budget simulated with the CCCma Earth System Model. J. Climate, 22, 6066-6088.

— - and Coauthors, 2011: Carbon emission limits required to satisfy future representative concentration pathways of greenhouse gases. Geophys. Res. Lett., 38, L05805, doi:10.1029/ 2010GL046270.

_- , and Coauthors, 2013: Carbon-concentration and carbonclimate feedbacks in CMIP5 Earth system models. J. Climate, 26, 5289-5314.

Bala, G., K. Caldeira, A. Mirin, M. Wickett, C. Delire, and T. J. Phillips, 2006: Biogeophysical effects of $\mathrm{CO}_{2}$ fertilization on global climate. Tellus, 58B, 620-627.

Balsamo, G., P. Viterbo, A. Beljaars, B. van den Hurk, M. Hirschi, A. K. Betts, and K. Scipal, 2009: A revised hydrology for the ECMWF model: Verification from field site to terrestrial water storage and impact in the integrated forecast system. J. Hydrometeor., 10, 623-643.

Boisier, J. P., and Coauthors, 2012: Attributing the impacts of landcover changes in temperate regions on surface temperature and heat fluxes to specific causes: Results from the first LUCID set of simulations. J. Geophys. Res., 117, D12116, doi:10.1029/ 2011JD017106.

Bonan, G. B., 2008: Forests and climate change: Forcings, feedbacks, and the climate benefits of forests. Science, 320, 14441449.

Brovkin, V., and Coauthors, 2006: Biogeophysical effects of historical land cover changes simulated by six Earth system models of intermediate complexity. Climate Dyn., 26, 587-600. T. Raddatz, C. H. Reick, M. Claussen, and V. Gayler, 2009: Global biogeophysical interactions between forest and climate. Geophys. Res. Lett., 36, L07405, doi:10.1029/ 2009GL037543.

Canadell, J. G., and Coauthors, 2007: Contributions to accelerating atmospheric $\mathrm{CO}_{2}$ growth from economic activity, carbon intensity, and efficiency of natural sinks. Proc. Natl. Acad. Sci. USA, 104, 18866-18870.

Carpenter, S., P. Pingali, E. M. Bennett, and M. B. Zurek, 2006: Millennium Ecosystem Assessment: Report of Scenarios Working Group. Vol. 2, Island Press, $551 \mathrm{pp}$.

Chase, T. N., R. A. Pielke, T. G. F. Kittel, R. R. Nemani, and S. W. Running, 2000: Simulated impacts of historical land cover changes on global climate in northern winter. Climate Dyn., 16, 93-105.

Christian, J. R., and Coauthors, 2010: The global carbon cycle in the Canadian Earth System Model (CanESM1): Preindustrial 
control simulation. J. Geophys. Res., 115, G03014, doi:10.1029/ 2008JG000920.

Claussen, M., and Coauthors, 2004: The global climate. Vegetation, Water, Humans and the Climate, P. Kabat et al., Eds., Springer, 33-58.

Coleman, K., D. S. Jenkinson, G. J. Crocker, P. R. Grace, J. Klír, M. Körschens, P. R. Poulton, and D. D. Richter, 1997: Simulating trends in soil organic carbon in long-term experiments using RothC-26.3. Geoderma, 81, 29-44.

Collins, W. J., and Coauthors, 2011: Development and evaluation of an Earth-system model-HadGEM2. Geosci. Model Dev., 4, 1051-1075.

Cox, P. M., 2001: Description of the TRIFFID dynamic global vegetation model. Hadley Centre Tech. Note 24, $17 \mathrm{pp}$.

Davin, E. L., and N. de Noblet-Ducoudré, 2010: Climatic impact of global-scale deforestation: Radiative versus nonradiative processes. J. Climate, 23, 97-112.

de Noblet-Ducoudré, N., and Coauthors, 2012: Determining robust impacts of land-use-induced land cover changes on surface climate over North America and Eurasia: Results from the first set of LUCID experiments. J. Climate, 25, 3261-3281.

Dickinson, R., A. Henderson-Sellers, and P. Kennedy, 1993: Biosphere-Atmosphere Transfer Scheme (BATS) version 1e as coupled to the NCAR Community Climate Model. NCAR Tech. Note NCAR/TN-387+STR, 80 pp.

Dufresne, J.-L., and Coauthors, 2013: Climate change projections using the IPSL-CM5 Earth system model: From CMIP3 to CMIP5. Climate Dyn., 40, 2123-2165, doi:10.1007/s00382-012-1636-1.

Dutra, E., G. Balsamo, P. Viterbo, P. M. A. Miranda, A. Beljaars, C. Schar, and K. Elder, 2010: An improved snow scheme for the ECMWF land surface model: Description and offline validation. J. Hydrometeor., 11, 899-916.

Ellis, E. C., 2011: Anthropogenic transformation of the terrestrial biosphere. Philos. Trans. Roy. Soc. London, 369A, 1010-1035.

Essery, R. L. H., M. J. Best, R. A. Betts, P. M. Cox, and C. M. Taylor, 2003: Explicit representation of subgrid heterogeneity in a GCM land surface scheme. J. Hydrometeor., 4, 530-543.

Feddema, J. J., K. W. Oleson, G. B. Bonan, L. O. Mearns, L. E. Buja, G. A. Meehl, and W. M. Washington, 2005: The importance of land-cover change in simulating future climates. Science, 310, 1674-1678.

Findell, K. L., T. R. Knutson, and P. C. D. Milly, 2006: Weak simulated extratropical responses to complete tropical deforestation. J. Climate, 19, 2835-2850.

Friedlingstein, P., and Coauthors, 2006: Climate-carbon cycle feedback analysis: Results from the $\mathrm{C}^{4} \mathrm{MIP}$ model intercomparison. J. Climate, 19, 3337-3353.

Gillett, N. P., V. K. Arora, D. Matthews, and M. R. Allen, 2013: Constraining the ratio of global warming to cumulative $\mathrm{CO}_{2}$ emissions using CMIP5 simulations. J. Climate, 26, 6844-6858.

Giorgetta, M., and Coauthors, 2013: Climate variability and climate change in MPI-ESM CMIP5 simulations. J. Adv. Model. Earth Syst., in press.

Goldewijk, K. K., A. Beusen, G. van Drecht, and M. de Vos, 2011: The HYDE 3.1 spatially explicit database of human-induced global land-use change over the past 12,000 years. Global Ecol. Biogeogr., 20, 73-86.

Goll, D. S., V. Brovkin, B. R. Parida, C. H. Reick, J. Kattge, P. B. Reich, P. M. van Bodegom, and Ü. Niinemets, 2012: Nutrient limitation reduces land carbon uptake in simulations with a model of combined carbon, nitrogen and phosphorus cycling. Biogeosciences, 9, 3547-3569.
Hazeleger, W., and Coauthors, 2010: EC-Earth: A seamless Earthsystem prediction approach in action. Bull. Amer. Meteor. Soc., 91, 1357-1363.

— dation of a new seamless Earth system prediction model. Climate Dyn., 39, 2611-2629.

Houghton, R. A., 2003: Revised estimates of the annual net flux of carbon to the atmosphere from changes in land use and land management 1850-2000. Tellus, 55B, 378-390.

— J. I. House, J. Pongratz, G. R. van der Werf, R. S. DeFries, M. C. Hansen, C. Le Quéré, and N. Ramankutty, 2012: Carbon emissions from land use and land-cover change. Biogeosciences, 9, 5125-5142.

Hourdin, F., and Coauthors, 2006: The LMDZ4 general circulation model: Climate performance and sensitivity to parametrized physics with emphasis on tropical convection. Climate Dyn., 27, 787-813.

House, J. I., I. C. Prentice, and C. Le Quere, 2002: Maximum impacts of future reforestation or deforestation on atmospheric $\mathrm{CO}_{2}$. Global Change Biol., 8, 1047-1052.

Hurtt, G. C., S. Frolking, M. G. Fearon, B. Moore, E. Shevliakova, S. Malyshev, S. W. Pacala, and R. A. Houghton, 2006: The underpinnings of land-use history: Three centuries of global gridded land-use transitions, wood-harvest activity, and resulting secondary lands. Global Change Biol., 12, 1208-1229.

_ , and Coauthors, 2011: Harmonization of land-use scenarios for the period 1500-2100: 600 years of global gridded annual land-use transitions, wood harvest, and resulting secondary lands. Climatic Change, 109, 117-161.

Johns, T. C., and Coauthors, 2006: The new Hadley Centre climate model (HadGEM1): Evaluation of coupled simulations. J. Climate, 19, 1327-1353.

Jones, C., C. McConnell, K. Coleman, P. Cox, P. Falloon, D. Jenkinson, and D. Powlson, 2005: Global climate change and soil carbon stocks; predictions from two contrasting models for the turnover of organic carbon in soil. Global Change Biol., 11, 154-166.

, and Coauthors, 2011: The HadGEM2-ES implementation of CMIP5 centennial simulations. Geosci. Model Dev., 4, 543-570.

- , and Coauthors, 2013: Twenty-first-century compatible $\mathrm{CO}_{2}$ emissions and airborne fraction simulated by CMIP5 Earth system models under four representative concentration pathways. J. Climate, 26, 4398-4413.

Jungclaus, J. H., and Coauthors, 2006: Ocean circulation and tropical variability in the coupled model ECHAM5/MPI-OM. J. Climate, 19, 3952-3972.

Klein Goldewijk, K., 2001: Estimating global land use change over the past 300 years: The HYDE database. Global Biogeochem Cycles, 15, 417-433.

Krinner, G., and Coauthors, 2005: A dynamic global vegetation model for studies of the coupled atmosphere-biosphere system. Global Biogeochem. Cycles, 19, GB1015, doi:10.1029/ 2003GB002199.

Lawrence, P. J., and Coauthors, 2012: Simulating the biogeochemical and biogeophysical impacts of transient land cover change and wood harvest in the Community Climate System Model (CCSM4) from 1850 to 2100. J. Climate, 25, 3071-3095.

Loveland, T. R., B. C. Reed, J. F. Brown, D. O. Ohlen, Z. Zhu, L. Yang, and J. W. Merchant, 2000: Development of a global land cover characteristics database and IGBP DISCover from $1 \mathrm{~km}$ AVHRR data. Int. J. Remote Sens., 21, 1303-1330.

Madec, G., 2008: NEMO ocean engine. Institut Pierre Simon Laplace Note du Pole de Modélisation 27, 367 pp. 
Marti, O., and Coauthors, 2010: Key features of the IPSL ocean atmosphere model and its sensitivity to atmospheric resolution. Climate Dyn., 34, 1-26.

Martin, G. M., and Coauthors, 2011: The HadGEM2 family of Met Office Unified Model climate configurations. Geosci. Model Dev., 4, 723-757.

Moss, R. H., and Coauthors, 2010: The next generation of scenarios for climate change research and assessment. Nature, 463, 747756.

Pielke, R. A., Sr., and Coauthors, 2011: Land use/land cover changes and climate: modeling analysis and observationa evidence. Wiley Interdiscip. Rev. Climate Change, 2, 828-850.

Pitman, A. J., and Coauthors, 2009: Uncertainties in climate responses to past land cover change: First results from the LUCID intercomparison study. Geophys. Res. Lett., 36, L14814, doi:10.1029/2009GL039076.

- F. B. Avila, G. Abramowitz, Y. P. Wang, S. J. Phipps, and N. de Noblet-Ducoudré, 2011: Importance of background climate in determining impact of land-cover change on regional climate. Nat. Climate Change, 1, 472-475.

- , and Coauthors, 2012: Effects of land cover change on temperature and rainfall extremes in multi-model ensemble simulations. Earth Syst. Dyn., 3, 213-231.

Pongratz, J., C. H. Reick, T. Raddatz, and M. Claussen, 2009: Effects of anthropogenic land cover change on the carbon cycle of the last millennium. Global Biogeochem. Cycles, 23, GB4001, doi:10.1029/2009GB003488.

,,--- , and — 2010: Biogeophysical versus biogeochemical climate response to historical anthropogenic land cover change. Geophys. Res. Lett., 37, L08702, doi:10.1029/ 2010GL043010.

Raddatz, T. J., and Coauthors, 2007: Will the tropical land biosphere dominate the climate-carbon cycle feedback during the twenty-first century? Climate Dyn., 29, 565-574.

Reick, C. H., T. Raddatz, V. Brovkin, and V. Gayler, 2013: The representation of natural and anthropogenic land cover change in MPI-ESM. J. Adv. Model. Earth Syst., doi:10.1002/ jame.20022, in press.

Riahi, K., and Coauthors, 2011: RCP 8.5-A scenario of comparatively high greenhouse gas emissions. Climatic Change, 109, 33-57.

Sato, H., A. Itoh, and T. Kohyama, 2007: SEIB-DGVM: A new dynamic global vegetation model using a spatially explicit individual-based approach. Ecol. Modell., 200, 279-307.

Sellers, P. J., and Coauthors, 1997: Modeling the exchanges of energy, water, and carbon between continents and the atmosphere. Science, 275, 502-509.

Shevliakova, E., and Coauthors, 2009: Carbon cycling under 300 years of land use change: Importance of the secondary vegetation sink. Global Biogeochem. Cycles, 23, GB2022, doi:10.1029/ $2007 \mathrm{~GB} 003176$.
Sitch, S., V. Brovkin, W. von Bloh, D. van Vuuren, B. Eickhout, and A. Ganopolski, 2005: Impacts of future land cover changes on atmospheric $\mathrm{CO}_{2}$ and climate. Global Biogeochem. Cycles, 19, GB2013, doi:10.1029/2004GB002311.

Sokolov, A. P., D. W. Kicklighter, J. M. Melillo, B. S. Felzer, C. A. Schlosser, and T. W. Cronin, 2008: Consequences of considering carbon-nitrogen interactions on the feedbacks between climate and the terrestrial carbon cycle. J. Climate, 21, 37763796.

Stevens, B., and Coauthors, 2013: The atmospheric component of the MPI-M Earth system model: ECHAM6. J. Adv. Model. Earth Syst., 5, 1-27, doi:10.1002/jame.20015.

Strassmann, K. M., F. Joos, and G. Fischer, 2008: Simulating effects of land use changes on carbon fluxes: Past contributions to atmospheric $\mathrm{CO}_{2}$ increases and future commitments due to losses of terrestrial sink capacity. Tellus, 60B, 583-603.

Taylor, K. E., R. J. Stouffer, and G. A. Meehl, 2012: An overview of CMIP5 and the experiment design. Bull. Amer. Meteor. Soc., 93, 485-498.

Thornton, P. E., and Coauthors, 2009: Carbon-nitrogen interactions regulate climate-carbon cycle feedbacks: Results from an atmosphere-ocean general circulation model. Biogeosciences, 6, 2099-2120.

van den Hurk, B., P. Viterbo, A. Beljaars, and A. Betts, 2000: Offline validation of the ERA40 surface scheme. ECMWF Tech. Memo. 295, 43 pp.

- — - and S. O. Los, 2003: Impact of leaf area index seasonality on the annual land surface evaporation in a global circulation model. J. Geophys. Res., 108, 4191, doi:10.1029/ 2002JD002846.

Van der Molen, M. K., B. J. J. M. van den Hurk, and W. Hazeleger, 2011: A dampened land use change climate response towards the tropics. Climate Dyn., 37, 2035-2043.

van Vuuren, D. P., and Coauthors, 2011: RCP2.6: Exploring the possibility to keep global mean temperature increase below $2^{\circ} \mathrm{C}$. Climatic Change, 109, 95-116.

Vitousek, P. M., H. A. Mooney, J. Lubchenco, and J. M. Melillo, 1997: Human domination of Earth's ecosystems. Science, 277, 494-499.

von Storch, H., and F. W. Zwiers, 1999: Statistical Analysis in Climate Research. Cambridge University Press, $484 \mathrm{pp}$

Watanabe, S., and Coauthors, 2011: MIROC-ESM 2010: Model description and basic results of CMIP5-20c3m experiments. Geosci. Model Dev., 4, 845-872.

Weiss, M., B. van den Hurk, R. Haarsma, and W. Hazeleger, 2012: Impact of vegetation variability on potential predictability and skill of EC-Earth simulations. Climate Dyn., 39, 2733 2746.

Zaehle, S., P. Friedlingstein, and A. D. Friend, 2010: Terrestrial nitrogen feedbacks may accelerate future climate change. Geophys. Res. Lett., 37, L01401, doi:10.1029/2009GL041345. 
Copyright of Journal of Climate is the property of American Meteorological Society and its content may not be copied or emailed to multiple sites or posted to a listserv without the copyright holder's express written permission. However, users may print, download, or email articles for individual use. 